\title{
A TEST SIMULATION OF THE TEMPERATURE OF THE ILLINOIS RIVER AND A PREDICTION OF THE EFFECTS OF DRESDEN II AND DRESDEN III REACTORS
}

R. T. Jaske

April 1968

\section{AEC RESEARCH \& DEVELOPMENT REPORT}




\section{LEGAL NOTICE}

This report was prepared as an account of Government sponsored work. Neither the United States, nor the Commission, nor ony person acting on beholf of the Commistion.

A. Makes any warranty or representotion, expressed or implied, with respect to the occuracy, complefeness, or usefulness of the information contained in this report, or that the use of any information, apparofus, method, or process disclosed in this repori moy not infringe privately owned rights: or

B. Assumes any liabilities with respect: to the use of, or for domoges resulting from the use of any Information, apparatus, method, or process disclored in this report.

As used in the obove. "person acting on behalf of the Commission" includes any employee or contractor of the Commission, or employee of such contractor, to the extent that such employee or contractor of the Commission, or employee of such contractor prepares, disseminetes, or provides occess to; any informotion pursuant to his employment or contract with the Commission, or his employment with wich controctor.

\section{PACIFIC NORTHWEST LABORATORY \\ RCHLAND, WASHINGTON \\ operated by \\ BATTELLE MEMORIAL INSTITUTE \\ for the}

UNITED STATES ATOMIC ENERGY COMMISSION UNDER CONTRACT AT(45-1)-1B30 
BNWL - 728

UC-2, Genera1, Miscellaneous, and Progress Reports

\section{A TEST SIMULATION OF THE TEMPERATURE \\ OF THE ILLINOIS RIVER AND A PREDICTION OF THE EFFECTS \\ OF DRESDEN II AND DRESDEN III REACTORS}

\section{By}

\section{R. T. Jaske}

Water and Land Resources Section

Environmental and Radiological Sciences Department

Apri1 1968 
Printed in the United States of America Available from

Clearinghouse for Federal Scientific and Technical Information National Bureau of Standards, U.S. Department of Commerce Springfield, Virginia 22151

Price: Printed Copy $\$ 3.00$; Microfiche $\$ 0.65$ 
TABLE OF CONTENTS

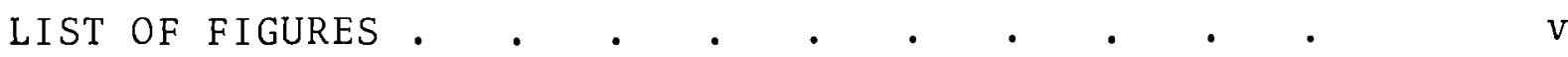

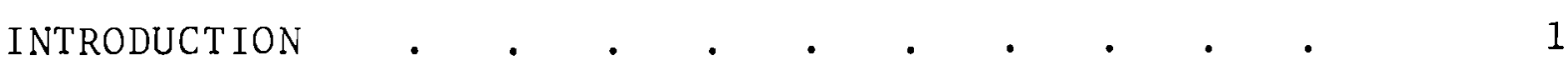

SUMMARY AND CONCLUSIONS •

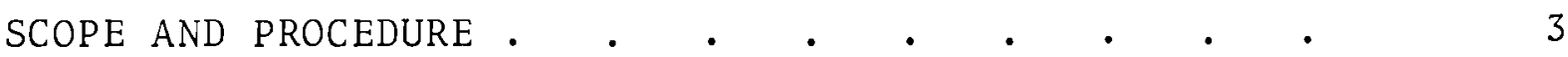

Objectives . . . . . . . . . . . • • • •

Basic Description of the Digital

Simulation System . . . . . . . . . . . 5

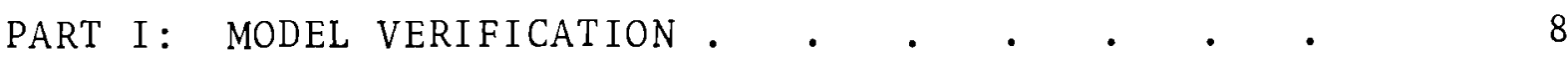

Physical Site Factors . . . . . . . . .

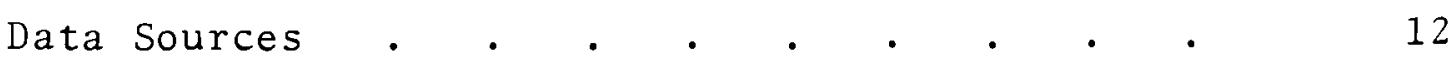

River Sections..$\quad$. . . . . . . . 12

Flow Records . . . . . . . . . . 13

Weather Records . . . . . . . . 13

Water Temperature Data. . . . . . 14

PART II: PROJECTED CONDITIONS (1972) . • • . . 20

Advected Heat Quantities . . . . . . . 20

Results of Simulation Analysis . . . . . . 21

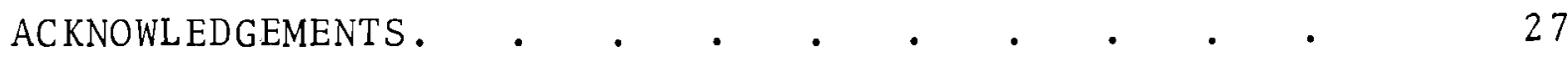

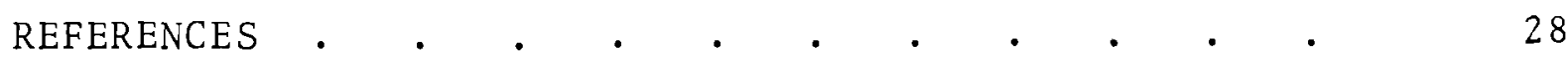

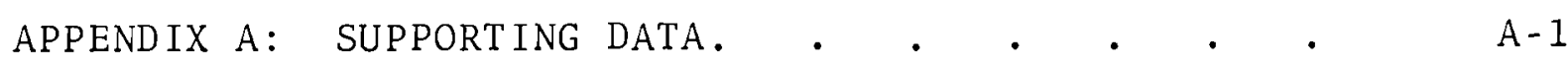

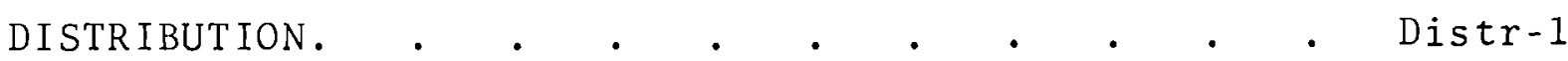




\section{LIST OF FIGURES}

1 Flow Diagram, Water Quality Simulation

2 Illinois Waterway-Mile 220 to Lake Michigan

3 Dresden Island Lock and Dam Just Below the Commonwealth Edison Plant Site

4 Starved Rock Lock and Dam Located 40 Miles

Below the Commonwealth Edison Plant

5 Data on the Average, High, and Low Water Temperature of the Illinois Waterway at Smith's Bridge, Mile 278 (from Illinois Water Survey)

6 Data on the Average, High, and Low Water Temperature of the Illinois River at Marseilles, 1951-61;

River Mile 251

7 Computed Temperatures at Ottawa for 1963 Fitted to 10 yr Envelope of Extremes for 1950-60

8 Computed Temperatures at Ottawa for 1964 Fitted

to 10 yr Envelope of Extremes for 1950-60

9 Comparison of Measured and Computed Temperatures for $39 \mathrm{Mile}$ Reach Below the Dresden Reactor Plant

10 Monthly Mean Water Temperature-Illinois Waterway

11 Computed Temperatures for Marseilles Mile 249;

Effect of 3,541 MW Thermal Addition 20 Miles Below the Dresden Site is Demonstrated

12 Equilibration Distance for Varying Degrees

of Power Development at the Dresden Site

A-1 Fitted Curve for 10 yr Month1y Average Used as Input Temperature for al1 Cases

A-2 Fitted Curve for Computed Water Temperatures at Ottawa for Mile 230-No Advected Heat

A-3 Fitted Curve for Computed Water Temperatures at Ottawa for Mile 230-395 MW Continuous Advection 
A-4 Fitted Curve for Computed Water Temperatures at Ottawa for Mile 230-1,968 MW Continuous Advection A -5

A-5 Fitted Curve for Computed Water Temperatures at Ottawa for Mile 230-1,968 MW Continuous Plus $1,573 \mathrm{MW}$ Intermittant

A-6 Fitted Curve for Computed Water Temperatures at Ottawa for Mile 230-3,541 MW Continuous Advection 
A TEST SIMULATION OF THE TEMPERATURE OF THE ILLINOIS RIVER AND A PREDICTION OF THE EFFECTS OF DRESDEN II AND DRESDEN III REACTORS

$$
\text { R. T. Jaske }
$$

\section{INTRODUCTION}

At the request of the Environmental and Sanitary Engineering Branch, Division of Reactor Development and Technology, USAEC, two test simulations that involve application of the digital simulation system were performed. Actual data collected at two widely differing drainage basins were used. These basins were selected as cases by the AEC and Battelle-Northwest because of the extensive information available.

This report summarizes the results of the Illinois River simulation and the prediction of the effects of the thermal loading to be imposed by the operation of Dresden II and Dresden III reactors, which are presently planned for startup during the current calender year. The environmental records used were those collected by the Illinois Water Survey during 1950-60, the United States weather Bureau, and from thermographs installed in 1967 under this program for additional verification. Primary emphasis in the study is accorded to the weather year 1964, a year arbitrarily selected at the on-set of the program because of the availability of the weather data at that time.

The Illinois Waterway has achieved national significance as an example of a totally planned stream. Since the early days of the reversal of the flow of the Chicago River, successive projects dedicated to sanitary waste transport and navigation have created a highly industrialized waterway.

A great deal of information concerning the physical characteristics of the waterway is available which makes it ideal for 
the study by simulation techniques. While the present case is limited to temperature studies, the basic principles of the simulation system are applicable to other conservative and nonconservative materials transported in water and interchanged with the atmosphere. (1)

Of special importance was the existance of a well defined temperature record which originated with the Illinois Water Survey and was used as the basis for the simulation application.

\section{SUMMARY AND CONCLUSIONS}

- The COL HEAT simulation system is generally adequate to represent the water temperature of the Illinois River within the accuracy of the available data record. This application disclosed no serious application problems of the basic simulation system, but did point out several areas in which improvements in the processing of stream dimensional data are required. The case studies use weather data from the Chicago Midway airport supplemented by solar radiation measurements taken routinely by the AEC at Argonne National Laboratory.

- In addition to the successful simulation of the basic river temperature records as defined in the case study, the study forecasts significant alteration of the present thermal regime of the Illinois River 39 miles downstream at Ottawa, the lower limit of the present case study. On a yearly average basis, about $70 \%$ of the heat of the present Dresden plant is dissipated to the atmosphere at that point. This is expected to decrease to about $60 \%$ for the combination of Dresden I and II, and to about $50 \%$ for the combined heat load of the three plants.

- Load cycling effects are leveled out at distances below the plant to the extent that the residual heat carried downstream is generally proportionate to the integrated gross input at the point of release. 
- The application of the simulation to a large slowly moving waterway such as the Illinois does not introduce any new problems within the validity of the original assumptions. Field measurements indicate that even with a stream velocity as low as $0.20 \mathrm{ft} / \mathrm{sec}$, sufficient turbulence is generated to cause vertical mixing on a scale sufficient to essentially eliminate stratification and the formation of density underflows. The field data taken for this simulation support the validity of Debler's use of the densimetric Froude number as an index of the stratifying tendency of rivers and reservoirs. (2)

- On the basis of the successful application of the COL HEAT model to this case, and that of the Deerfield River, the system appears to have sufficient merit to support application to a larger, regional stream system. With the approval of the Division of Reactor Development and Technology, the upper Mississippi, (Region 5 as defined by the United States Geological Survey, USGS,) has been selected as the next area for examination. The objective of this case is to explore the practical limits of the use of direct cooling for the projected level of thermal power plant expansion which is anticipated in the most recent forecast of the Federal Power Commission in relation to applicable State standards.

\section{SCOPE AND PROCEDURE}

\section{OBJECTIVES}

The objectives of the Illinois River simulation included the following:

- Demonstration of the applicability of the COL HEAT simulation model developed by Battelle-Northwest to the Illinois River in a manner that would demonstrate both the 
validity of the results and the ease of application to other basins or drainage systems which may require detailed examination.

- Prediction of the downstream effects of the two additional direct-cooled nuclear generating plants presently under construction at the Dresden site of the Commonwealth Edison Company

These objectives were identified by the Division of Reactor Development and Technology (DRDT) in response to the needs for a balanced program of envixonmental investigations. The continued growth of the thermal electrical generation along the line of the Gompertz compound growth curves, and the apparent saturation of hydroelectric capability for base loading at about the present level serve to draw additional attention to the need for better understanding and planning of heat rejection. In response to the revised Federal Water Pollution Act, the States are establishing water quality standards that will be implemented in the immediate future. The standards are chosen on the basis of existing knowledge from ecological and physical studies and usually specify upper limits on the temperatures of streams. Such limits can be expected to have general application; therefore, it is desirable to develop techniques which can serve 1) to determine the specific effects of industrial plants with high heat rejection and 2 ) to permit apportionment of available ther. mal gradients on a rational basis.

The work described in this report and the supporting research program which has been authorized by DRDT is a direct extension of the operations research modei which was developed to evaluate the effectiveness of the annual Columbia River tem perature enhancement program formerly carried out annually by the Division of Production. (4) In planning the projected regional systems, associated load growth projections from the 
Conceptual Reactor Design Program (a1so assigned to BattelleNorthwest by DRDT) have been made. The entire effort is expected to utilize to the maximum extent 1 ) the systems modeling experience gained from AEC operation of the Hanford plant and 2) the existing government data resources in stream hydrology and weather data, without the necessity for creation of an extensive new data collection program.

\section{BASIC DESCRIPTION OF THE DIGITAL SIMULATION SYSTEM}

The COL HEAT simulation model has been described in previous reports and publications, ${ }^{(1)}$ and has been used extensively both on the Columbia River and other tributary systems for the operational analysis of the effects of industrial development. (5) The computational system operates on the assumption that most streams will be turbulent or supercritical in hydraulic characteristics and, that within this assumption, the distribution of velocity within the stream is similar regardless of the stream dimensions. Based on this concept, the model sets up a series of difference equations derived from the heat budget method and iteratively computes the downstream temperatures as a function of the input parameters in the following manner:

$$
\begin{aligned}
T_{i} & +1, j+1=(1-B)\left(T_{i, j}+\Delta T_{i, j}^{(1)}+\Delta T_{i, j}^{(2)}\right)+B\left(T_{i, j-1}+\Delta T_{i, j-1}^{(1)}\right. \\
& \left.+\Delta T_{i, j}^{(2)}\right)
\end{aligned}
$$

where $\mathrm{T}_{\mathrm{i}, \mathrm{o}}=$ average temperature of water entering the system during the $i^{\text {th }}$ time interval, ${ }^{\circ} \mathrm{C}$

$\mathrm{T}_{i, j}=$ average water temperature of the beginning of the $j^{\text {th }}$ flow, and flow increment at the end of the $i^{\text {th }}$ time increment (flow day) ${ }^{\circ} \mathrm{C}$ 

$\begin{aligned} \Delta T_{i, j}^{(1)}= & \text { the temperature change during the first half of } \\ & \text { the } i^{\text {th }} \text { time interval in the } j \text { flow increment }\end{aligned}$ as determined from surface heat exchange plus advected energy (heat budget) in ${ }^{\circ} \mathrm{C}$ $\begin{aligned} \Delta \mathrm{T}_{i, j}^{(2)}= & \text { same as above except for the second half of the } \\ & i^{\text {th }} \text { time interval, in }{ }^{\circ} \mathrm{C}\end{aligned}$ $\Delta T_{i, j}^{(1)}=T_{i, j}+T_{i, j}^{(1)}$

$B=$ the fractional part of the water in the inner fast moving trough.

Since density currents can cause appreciable error in the heat budget calculation, the overall system heat budget must include analysis of this effect where applicable. Density currents in the rapidly flowing river are stable only when reinforced by heat input, which produces a density gradient greater than that required for maintenance of a densimetric Froude number of 0.28 or less. (2) Accordingly, the existence of density currents in stratifying reservoirs must be verified constantly. The thermal version of the model is verified by the process delineated in the notes of Figure 1 . The additional subroutine, SMATCH, is used in the actual model to correlate and match the appropriate water masses as they pass through the reservoir or river section in question.

The following data are required for operation of the temperature model:

- Water temperature at the inlet end (time increment appropriate)

- Flow discharge at the outlet end

- Water temperature at the outlet end (optional, for statistical comparison where available)

- Meteorological parameters (wind velocity for time period, mean air temperature, dew point, sky cover in tenths, short wave radiation) 


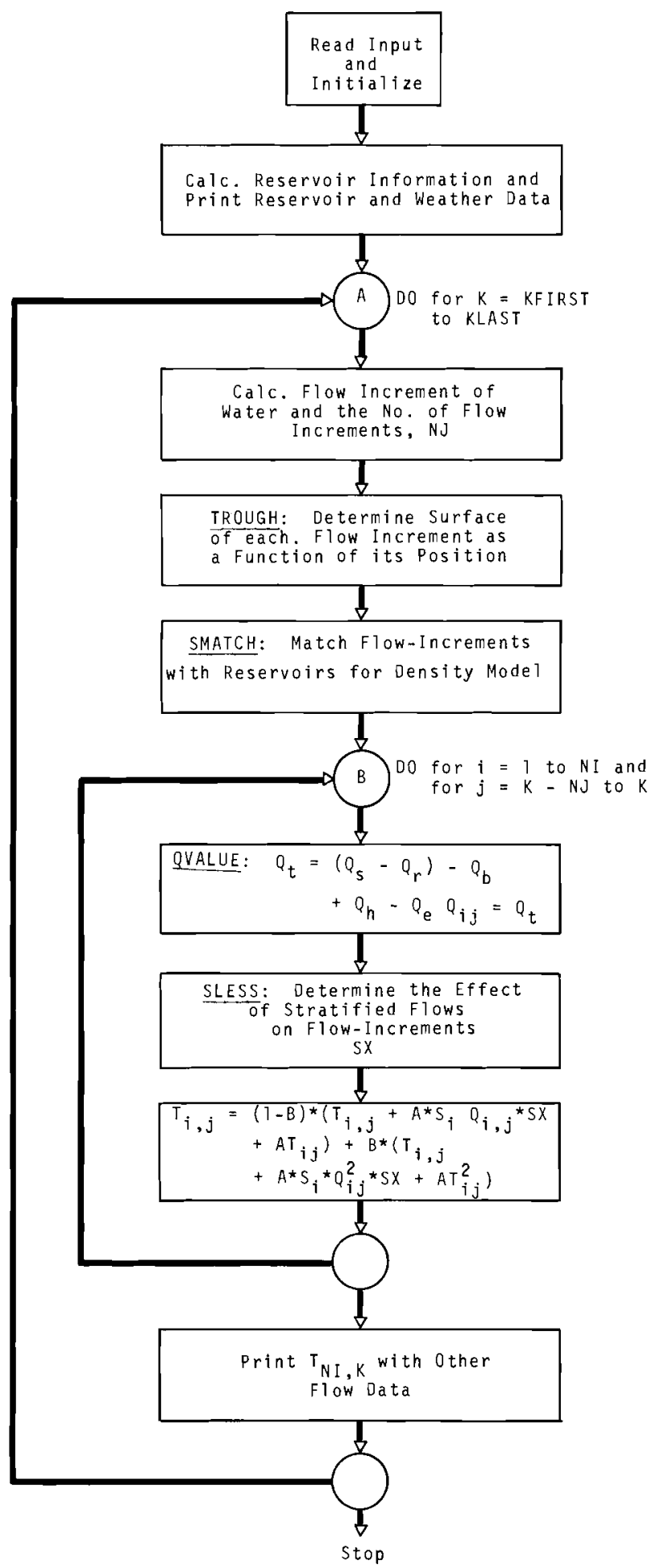

FIGURE 1. FLow Diagram, Water Quality Simulation 
- River or reservoir dimensions reduced to equivalent nonparallel trapezoidal cross sections (volume, surface or bottom areas are derived)

- Advected heat quantities (megawatts per time incrementation).

Computations can be made for any incrementation time for which data are available; for instance, daily incrementation is required for use with daily average data, and hourly average data are required for hourly incrementation.

\section{PART I: MODEL VERIFICATION}

\section{PHYSICAL SITE FACTORS}

The scope of this phase of the simulation covers the Illinois Waterway from Mile 278, at a location above the Dresden plant where temperature records were available, to downstream River Mile 230 just below the outlet works of the Starved Rock Lock and Dam. The general relationship of the main waterway and the tributary streams is illustrated in Figure 2. The Illinois Waterway was formed as a result of construction of the Sanitary Ship Canal in 1893. Later modifications include a series of control dams between Chicago and the Mississippi River (see Figures 3 and 4 ). In more recent years, the question of the quantity of water diverted through the system has received extensive public review. A decision of the court appointed water master has sustained the present mode of operation, and it is expected that the fiow currently being discharged represents a sound basis for the reconnaissance investigation of the thermal effects of the new Dresden plants.

Compared with the Columbia River, where the simulation model was originally tested, the flow regime of the Illinois River is quite torpid, and, as a case example, tests the lower limit of the stream velocity for which the model can be said 


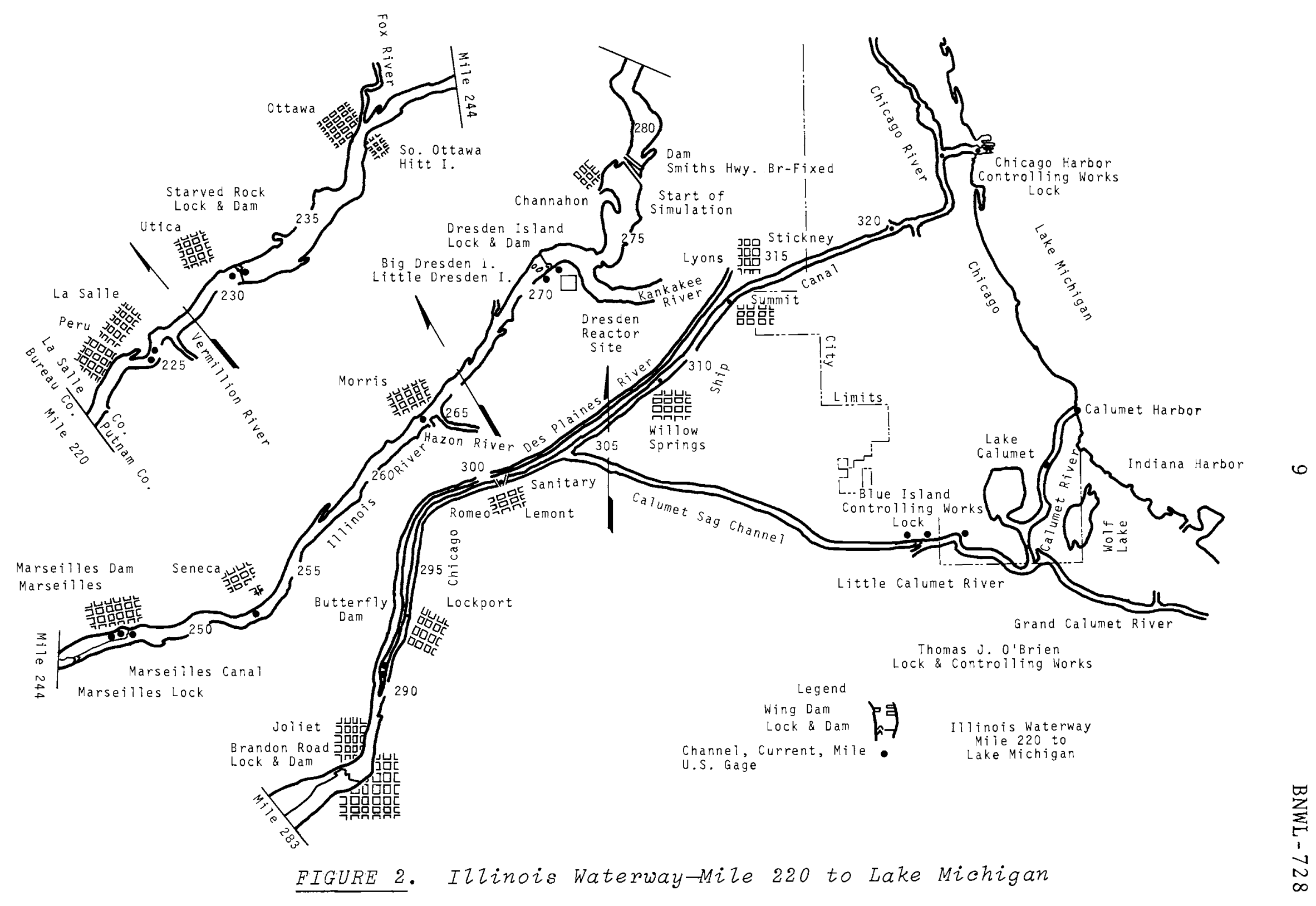




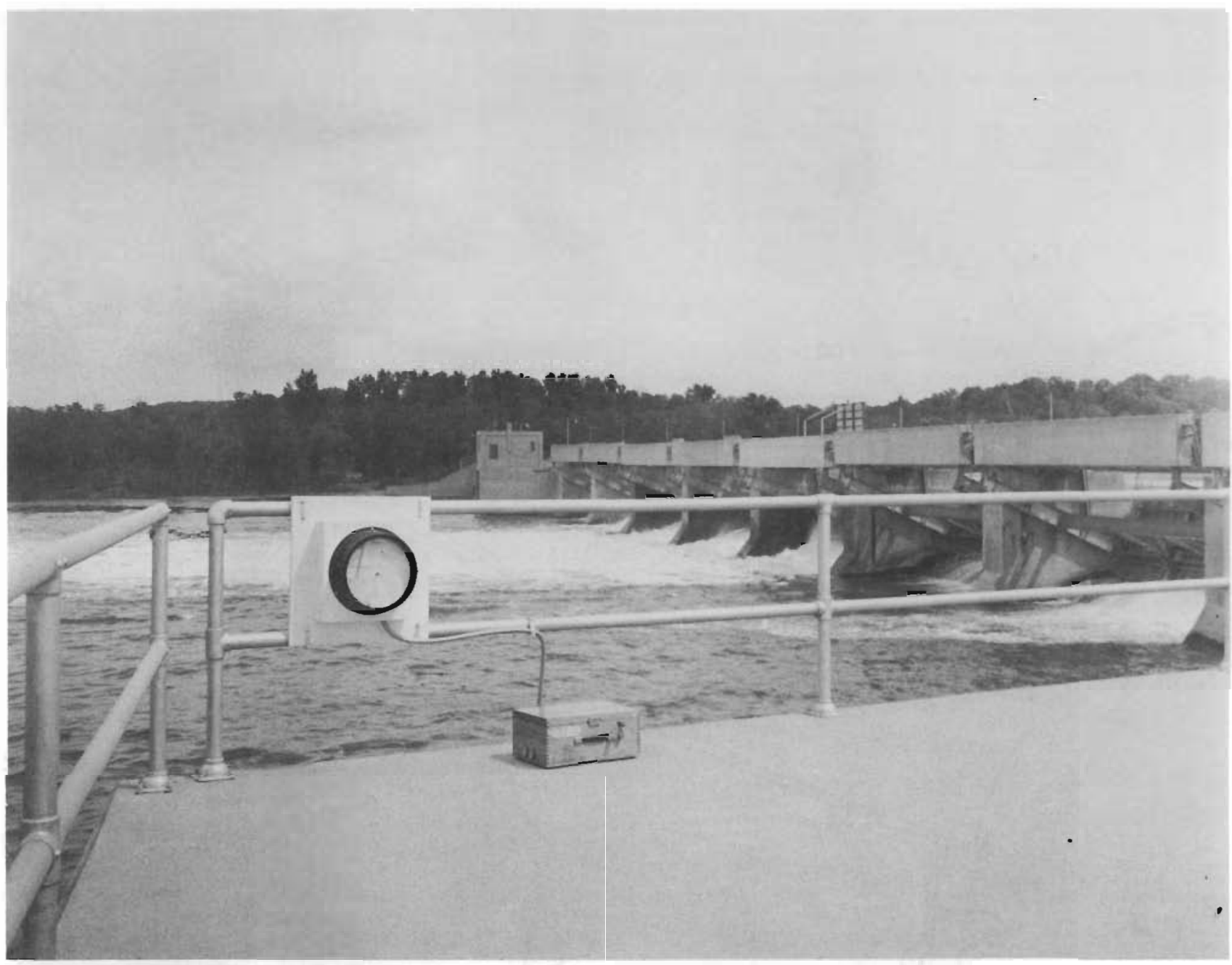

FIGURE 3. Dresden Island Lock and Dam Just Below the Commonwealth Edison Plant Site 


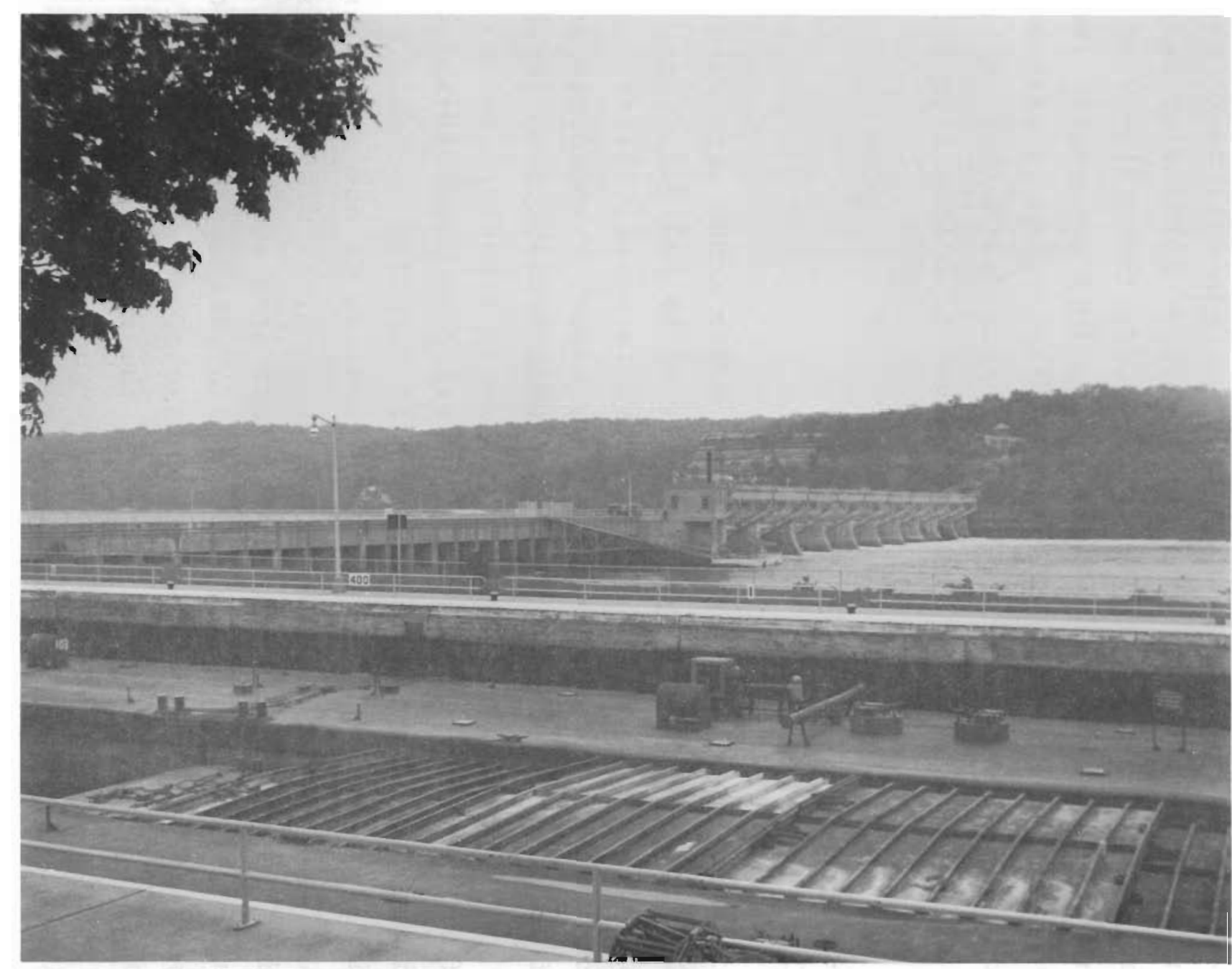

FIGURE 4. Starved Rock Lock and Dam Located 40 Miles Below the Commonwealth Edison Plant 
unquestionably to apply. A primary assumption of turbulent mixing is required in the model concept. Computations of the equilibrium temperatures of the epilimnion of stratified reservoirs using the COL HEAT model yield good representations of the average temperatures in that region. This apparently indicates that the turbulent diffusivity of the region is adequate to support the mixing concept. Orlob concurs with this in his studies of TVA reservoirs, (6) where values of D from 1 to 8 $\mathrm{cm}^{2} / \mathrm{sec}$ have been calculated.

\section{DATA SOURCES}

\section{River Sections}

Excellent soundings for the reach under study were made available from the Department of Public Works and Buildings, State of Illinois. These soundings down to Depue, I11inois, are an updated version of original Sanitary District soundings and Corps of Engineers records. Contours were available to tenths of feet surface profile elevation and depth soundings to $0.5 \mathrm{ft}$. This information was processed in the standard model format of seven dimensions per selected section as compiled in Table A-I (Appendix A). Since the bottom configuration is not always an ideal trapezoid, some adjustment of the physical dimensions is required. Where this is done the surface area and the total volume are conserved and the dimensions of the trapezoidal section adjusted appropriately. In the case of the Illinois River, a small portion of the edges of the river consists of sloughs and oxbow lakes which are submerged at higher water. The water in these volumes was neglected in developing the idealized channel. Tests made with the stream dimensions greatly modified reveal little sensitivity of the computations to errors in stream volume except in the timing of transient events. In this case, transient events were of little consequence, and due to the conservative nature of the computations, the peripheral volumes and ground water exchange were neglected. 
There is a temptation to extend the scope of temperature analyses to include the advected heat from ground water flows. Little evidence exists, however, to support the added time and expense of doing so in most cases of thermal simulation. Where sufficient time and data are available, the COL HEAT model has currently unused subroutines which can handle advected flow quantities and dead storage from sloughs and ground water. Such cases could include pesticide dilution and advection from irrigation or drainage where the concentration mode of the model is being utilized. These flows are of great importance in assessing the flow quantities through the drainage system on a annual basis. This is especially true in the lower river below Kingston Mines where, for a stretch of some 150 miles, no suitable gaging station exists because of the highly variable effects of bank and ground water storage on the intregated stream discharge into the Mississippi.

Flow Records

River flow records are routinely published by the USGS and are more than adequate for the reconnaissance simulation of most United States rivers. For this case, records were obtained directly from magnetic tape storage of the USGS. These were supplemented with current 1967 data where month by month verification was carried out. Daily average flows for the Illinois River were used as measured at Marseilles, I11inois .

Weather Records

Weather data were obtained directly from the magnetic tape files of the United States Weather Bureau at Asheville, North Carolina. Existing data were compiled in card images at Asheville, and forwarded to Richland for computer operation. Data for Chicago, Midway Airport, and Peoria, I11inois, were used in the study as well as solar radiation data obtained from Argonne National Laboratory at Lemont, I11inois. 
Statistical comparison of these two data locations show sufficient correlation to permit their use throughout the entire reach down to Mile 80 where additional simulation runs are currently under way. This concept has been tested in the Deerfield simulation, (3) and forms one of the basic assumptions of the COL HEAT simulation system. Because of the open nature of the Illinois River, the values for the various coefficients for surface heat exchange were identical to those used in the Lake Hefner study. (7) The Bowen ratio was assumed constant throughout the entire seasonal cycle.

Water Temperature Data

The entire study is dependent upon the excellent compilation of water temperatures made by the Illinois Water Survey during the years 1950-60 and published in Reference 8. However, in compiling this record in monthly average format, the original daily or analog readings from the thermographs were statistically treated and filed, or are otherwise unavailable. Consequently, the simulation ability of the system cannot be checked directly except with current data which are being measured at Dresden Island Dam and Starved Rock Dam under this present program. This data record was started May 28, 1967, and is expected to be continued for several years after the Dresden reactors are in operation. An additional instrument is proposed for La Grange Lock and Dam at Mile 80 to complete the test of the system.

The indirect check of the simulation system has been conducted on the basis of the probability that temperatures computed for later years, such as 1963 and 1964, would fall within the envelope of maximums and minimums which are reported in the Illinois water Survey work ${ }^{(8)}$ (Figures 5 through 8 ). The procedure for making this simulation check is as follows: 


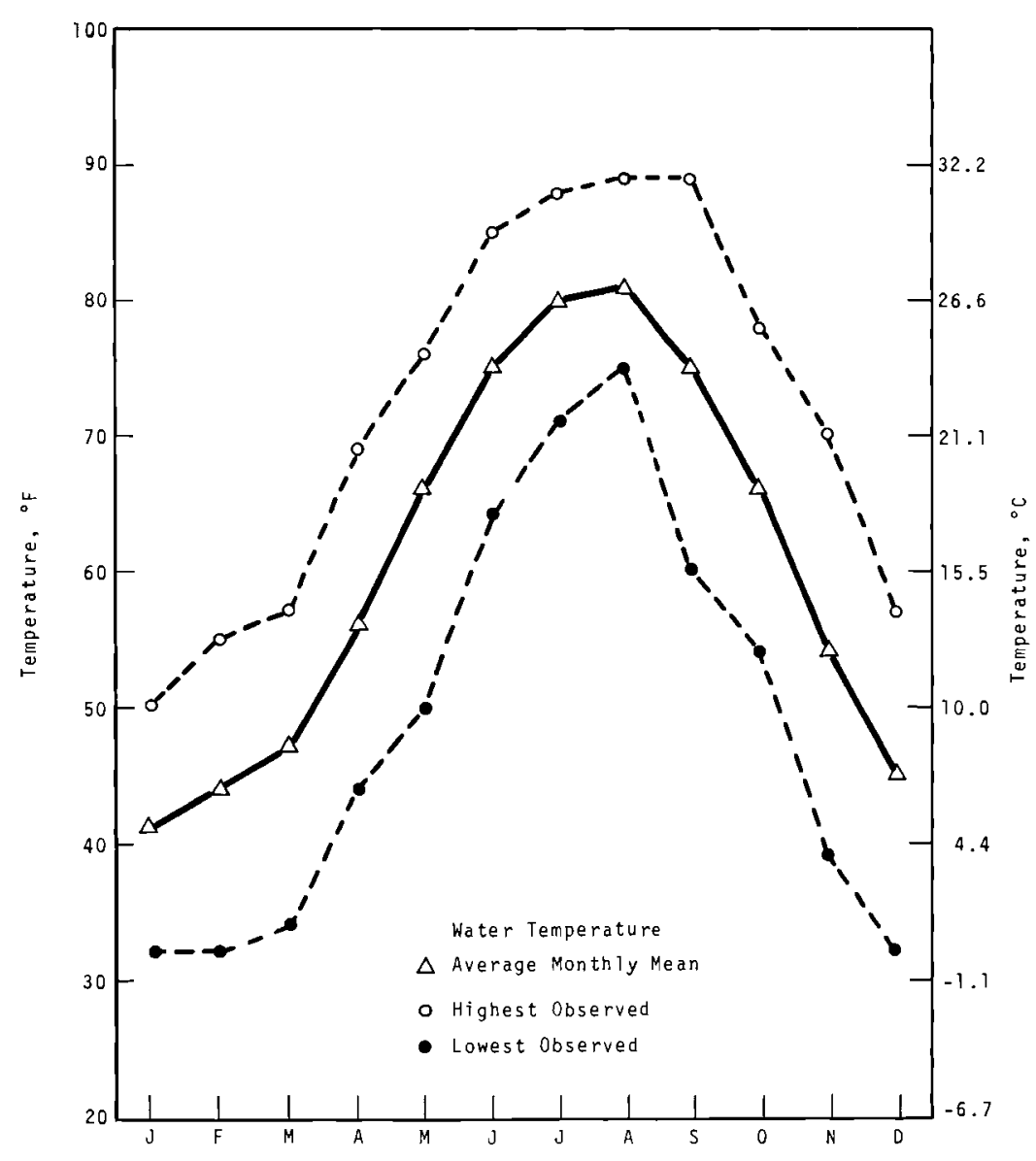

FIGURE 5. Data on the Average, High, and Low Water Temperature of the Ilzinois Waterway at Smith's Bridge, Mile 278 (from Illinois Water Survey)

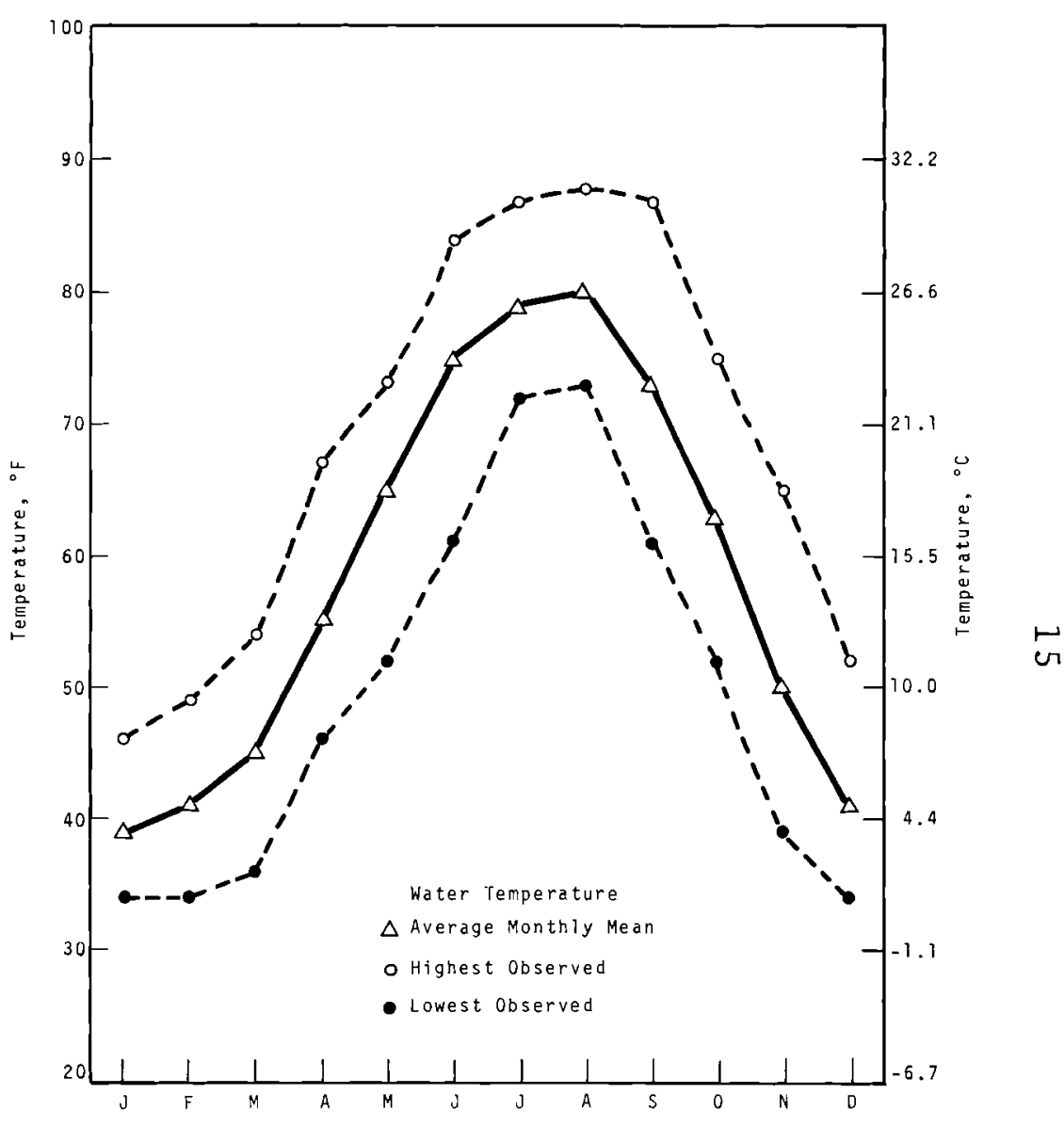

FIGURE 6. Data on the Average, High, and Low Water Temperature of the Illinois River at Marseizles, 1951-61; River Mile 251 


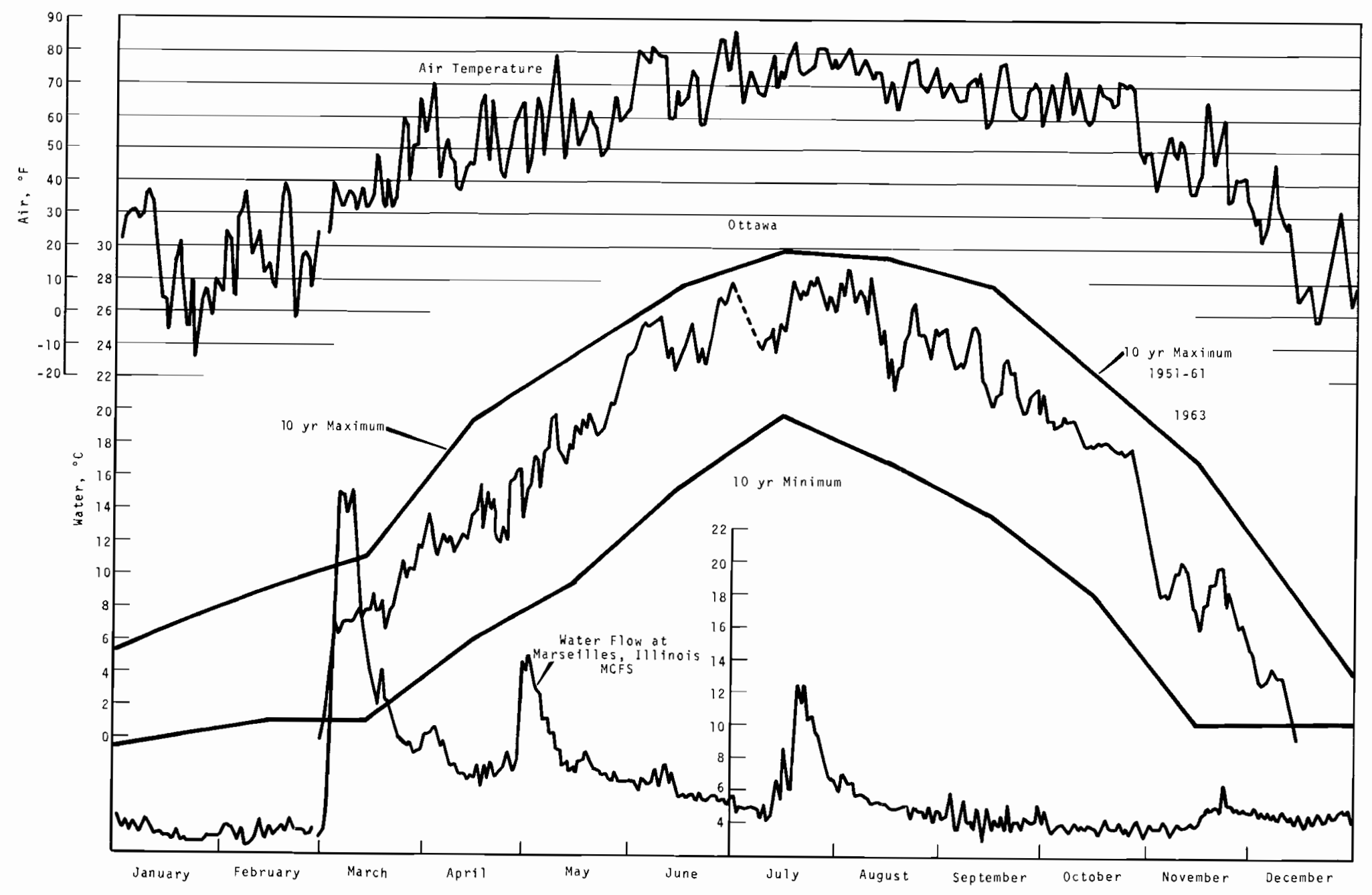




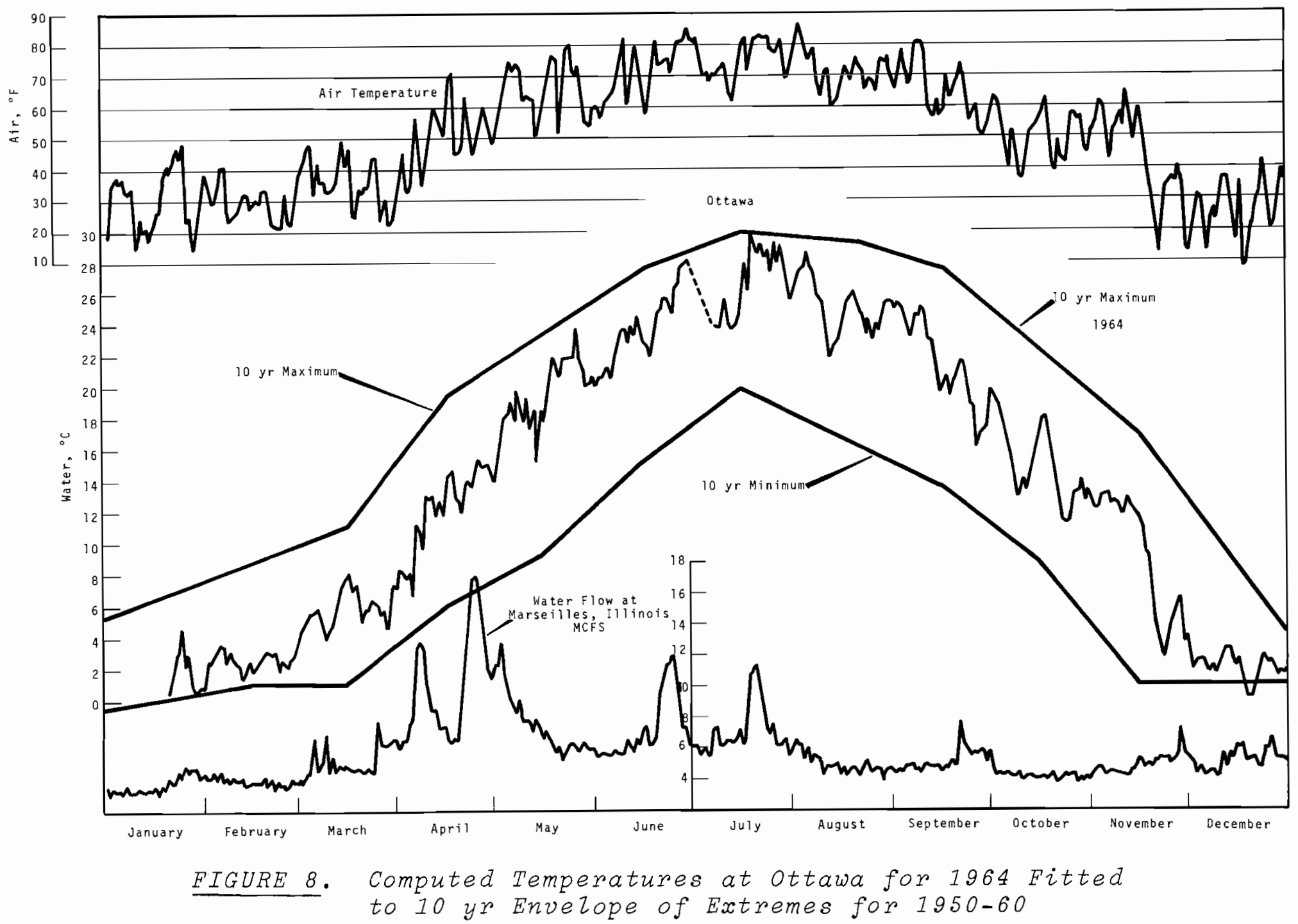


- Compile a daily average record by making a least square sine curve fit of the appropriate upstream point, in this case Smith's bridge, Mile 277 on the main tributary of the Des Plaines River.

- Using these data as the entering temperatures, compute the daily average temperature using either a long term average daily weather record, or as an alternative use later years which were not included in the original ten years.

- The test of simulation is to have a significant majority of the downstream computed temperatures fall within the envelope of extrems for the earlier years.

Figures 7 and 8 show this procedure for the years 1963 and 1964 superimposed on the envelope of extrems for the water data of 1950-60. The validity of this test has been discussed with various authorities including $W$. C. Ackermann, Director of the Illinois Water Survey. No significant objection has been indicated.

For comparison purposes, the actual data taken since May, 1967, are compared with the results of the machine computations for the same period. Figure 9 illustrates the ability of the simulation system to accurately indicate the daily average record for the $39 \mathrm{mile}$ reach between the two dams discussed above.

The temperature of side streams entering the main Illinois Waterway are essentially the same as those of the Waterway itself and do not significantly alter the basic regime. In general, the temperatures of the water originating in Lake Michigan and extensively heated by industrial discharges are hottest above River Mile 280 and form a long cooling trend in the passage of water into the Mississippi. Figure 10 is a summary of the average temperatures for three locations along the waterway for which data from the Survey Report 49 are available. 


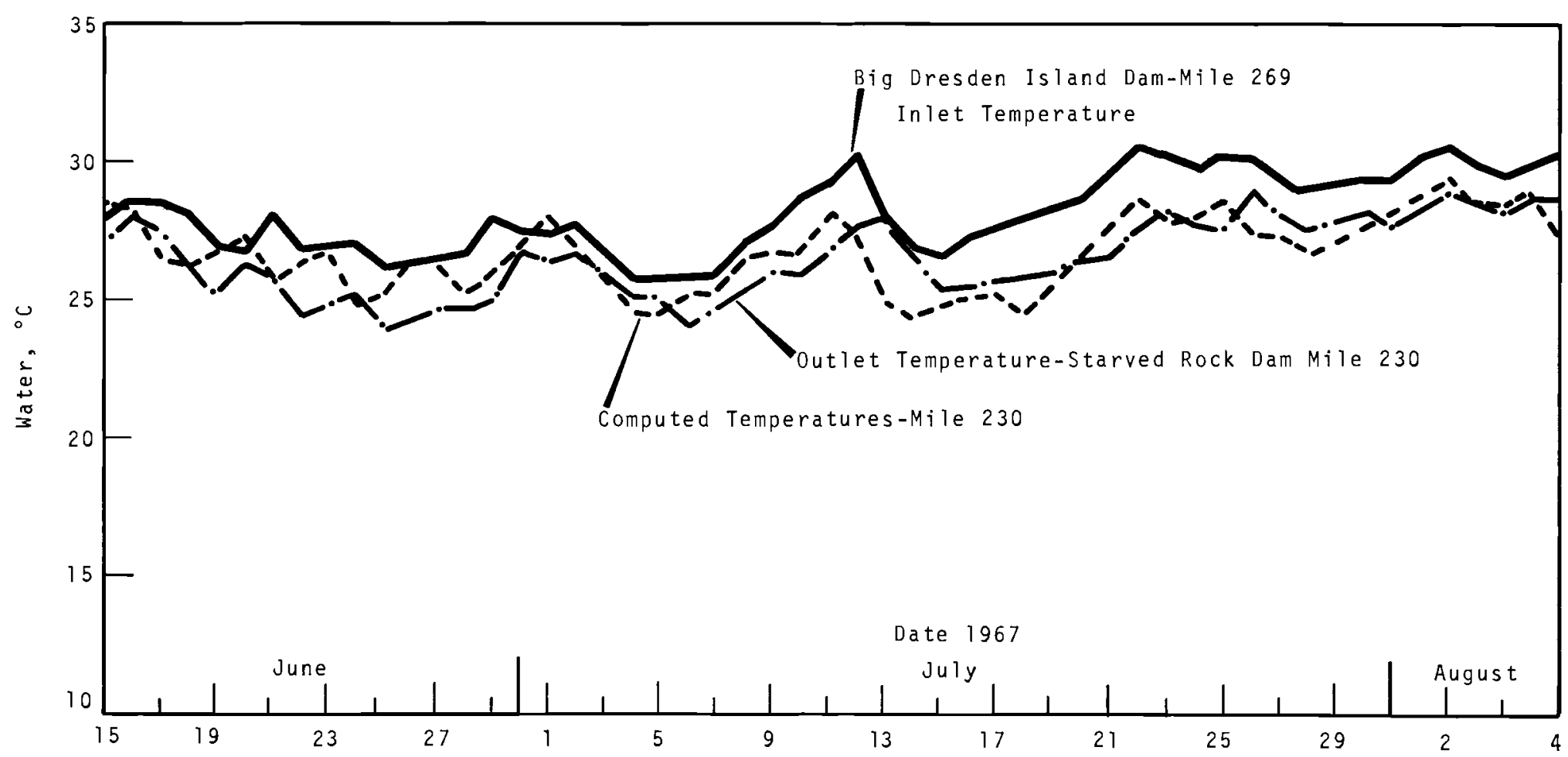




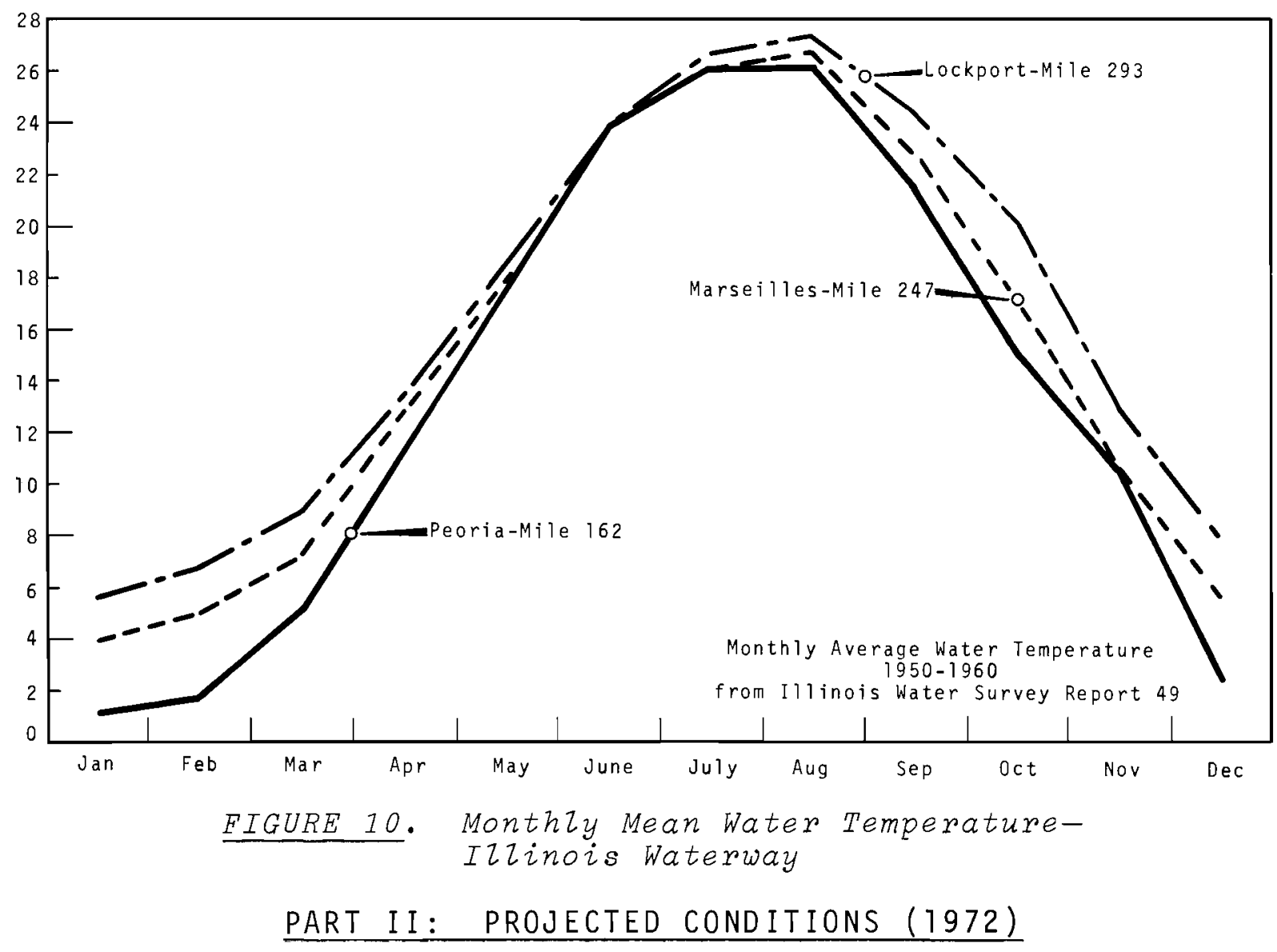

\section{ADVECTED HEAT QUANTITIES}

The anticipated thermal loading of the Illinois Waterway following the operation of new units at Dresden is based on the following plant data:

\section{TABLE I. Plant Ratings}

\begin{tabular}{|c|c|c|c|c|}
\hline & \multicolumn{2}{|c|}{ Rated Power, MW } & \multicolumn{2}{|r|}{ Start Up } \\
\hline Plant & Net Electrical & Gross Elect. & Therma 1 & Year \\
\hline resden I & 200 & & 700 & 1960 \\
\hline resden I I & 715 & 809 & 2300 & 1969 \\
\hline resden I I I & 715 & 809 & 2300 & 1970 \\
\hline
\end{tabular}

Construction work on the latter two units is now well advanced. An exact determination of the downstream temperature effects of the three projects operating in concert 
requires an extensive analysis beyond the scope of this preliminary study. However, for purposes of this analysis, some practical, simplifying assumptions regarding the nature of the expected plant load were made. These are summarized in the Case descriptions below:

\section{TABLEII. Assumed Thermal Inputs}

\begin{tabular}{|c|c|c|}
\hline Case & Plants Included & Thermal Input to River \\
\hline 0 & None & \\
\hline I & Dresden I & $395 \mathrm{MW}$ continuous \\
\hline I I & Dresden I \& II & $1968 \mathrm{MW}$ continuous \\
\hline I I I a & Dresden I, II $\&$ III & $3,541 \mathrm{MW}$ continuous \\
\hline I I I b & Dresden I, I I \& I I & $\begin{array}{l}1,968 \text { MW continuous plus } \\
1,573 \text { Monday through } \\
\text { Friday }(3,541 \mathrm{MW} \\
\text { Monday through } \\
\text { Friday) }\end{array}$ \\
\hline
\end{tabular}

Case I Ib was included to make some approximation of a load factoring case which reflected reduced demand over weekends. Other load factoring cases including hourly regulation can easily be accomodated by the basic computer program without additional development.

An investigation of other potential heat sources in the reach studied revealed none of a size large enough to seriously affect a reconnaissance analysis of the projected plants. This includes small side streams, such as the Fox River, that are relatively equilibrated and may, if anything, introduce a slight cooling effect on the overall system in the case of upward thermal modification of the main Waterway after the new plants are in operation.

RESULTS OF SIMULATION ANALYSIS

Computations of waterway temperature modification were based on daily average weather, stream flow and advected heat 
data for the years 1963 and 1964. These years were selected because the weather data were more easily available in punch card form from the National Data Center at Asheville. Input stream temperatures used were based on the development of a synthetic record derived wholly from the State of Illinois data published in Report 49 for the years 1950-60. A check with the instruments installed late in May 1967 under this study program reveal temperatures in the river quite similar to those reported earlier. Since the previous figures reveal a satisfactory simulation of the basic waterway temperature regime, this procedure appears fully justified.

The digital output for the four cases was compiled into a format capable of additional analysis using the method of fitting least squares sinusoidal models to an annual data set. This procedure has been developed to acquire a fully impartial method of trend analysis. This method and the application to a long term trend is reported in References 8 and 9 . It has been used to define trends of the temperature regime of the the Columbia River drainage basin. The actual fitted curves for Ottawa and Marseilles, as a result of plant operations for Cases I, II, IIIa and IIIb, are shown in Appendix A. The curves are for weather year 1964. No significant seasonal or annual differences in plant effects would be expected from those weather variations which would be diurnal or even of a weekly nature. Where short term effects are of interest, the original digital simulation output, also shown on the same illustrations, shows the actual daily average values computed from the test assumptions.

Figure 11 illustrates the typical output of the simulation for Case IIIb for the weather year 1964. The Marseilles location was selected. The fine structure of the temperature fluctuations with respect to flow changes and weather conditions are clearly revealed with respect to the comparative computation of Case 0 where no advected heat was considered. 


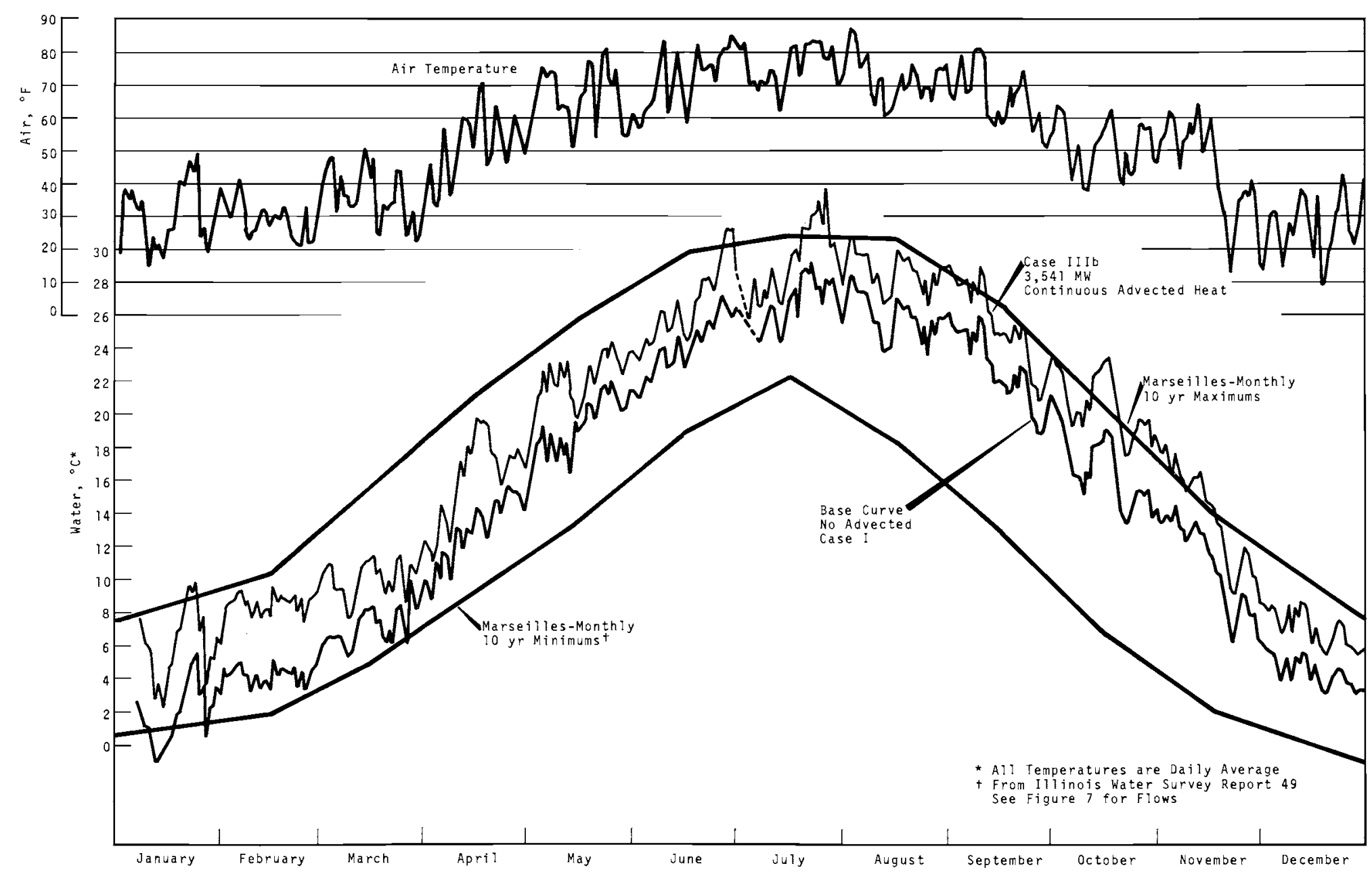


Finally, Figure 12 is a composite of the annual average, or first term of least squares functions which were fitted to the daily digital computations. Table III summarizes the entire set of functions derived for the year 1964. Appendix A contains reproductions of the actual Benson Lehner output produced in conjunction with the computer fitting of the listed functions.

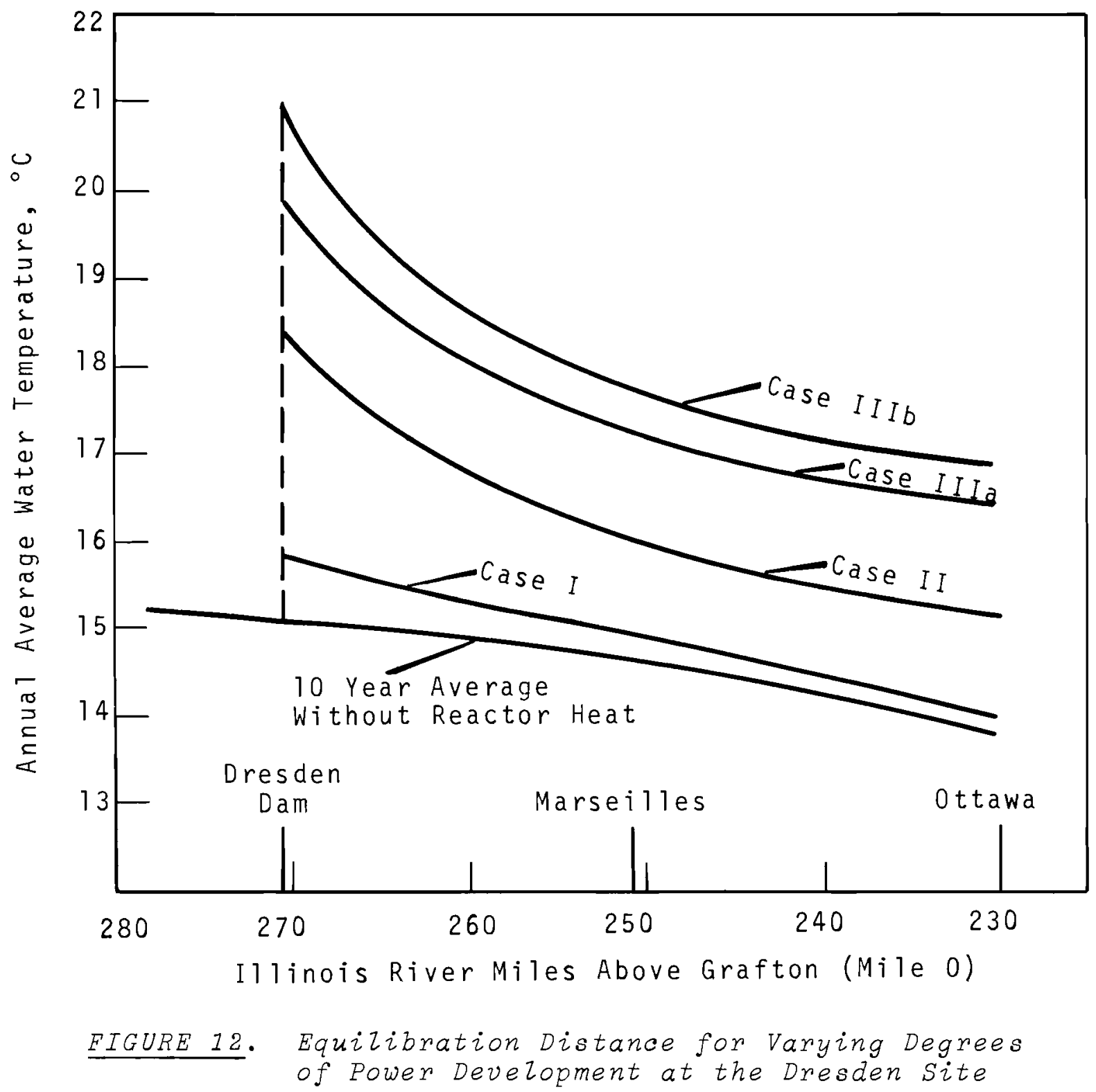


TABLE III. Summary of Least Squares Fitted Functions-1964

$$
\mathrm{T}=\overline{\mathrm{T}}+\mathrm{Bsin}(\mathrm{Cd}+\mathrm{D})
$$

where $\overline{\mathrm{T}}=$ Annual Average of Fitted Curve, ${ }^{\circ} \mathrm{C}$

$\mathrm{B}=$ Amplitude of Variation, ${ }^{\circ} \mathrm{C}$

$\mathrm{C}=$ Daily Progression-Radians-Nominally $\frac{2 \pi}{365}$

$\mathrm{d}=$ Number of Days

$\mathrm{D}=$ Radians from Year End for Peak Temperature Occurence Date $=365\left(1-\frac{D}{2 \pi}\right)$

\begin{tabular}{|c|c|c|c|c|c|c|}
\hline Case & Location & $\underline{\overline{\mathrm{T}}},{ }^{\circ} \mathrm{C}$ & $\underline{\mathrm{B},}{ }^{\circ} \mathrm{C}$ & $\mathrm{D},{ }^{\circ} \mathrm{C}$ & $\begin{array}{c}\overline{\mathrm{T}}-\mathrm{B} \\
\text { Computed } \\
\text { Annual } \\
\text { Min, }{ }^{\circ} \mathrm{C} \\
\end{array}$ & $\begin{array}{c}\overline{\mathrm{T}}+\mathrm{B} \\
\text { Computed } \\
\text { Annual } \\
\operatorname{Max},{ }^{\circ} \mathrm{C} \\
\end{array}$ \\
\hline Input & Smith's Bridge & 15.21 & 11.58 & 4.22 & 3.63 & 26.79 \\
\hline No Heat & Marseilles & 14.65 & 12.30 & 4.30 & 2.35 & 26.95 \\
\hline I & Marseilles & 14.91 & 12.27 & 4.34 & 2.33 & 28.87 \\
\hline I I & Marseilles & 16.10 & 11.94 & 4.29 & 4.16 & 28.04 \\
\hline I I a & Marseilles & 17.25 & 12.20 & 4.40 & 5.05 & 29.45 \\
\hline I I Ib & Marseilles & 17.65 & 12.10 & 4.37 & 5.45 & 29.75 \\
\hline No Heat & Ottawa & 13.76 & 13.21 & 4.37 & 0.55 & 26.97 \\
\hline I & Ottawa & 13.99 & 13.16 & 4.39 & 0.83 & 27.15 \\
\hline I I & Ottawa & 15.16 & 12.87 & 4.40 & 2.29 & 28.03 \\
\hline I I I a & Ottawa & 16.46 & 12.37 & 4.29 & 4.09 & 28.83 \\
\hline I I Ib & Ot tawa & 16.89 & 12.22 & 4.27 & 4.67 & 29.11 \\
\hline
\end{tabular}

Both the data in Table III and the summary curves for equilibration distance on Figure 12 yield important data regarding the expected effects of the proposed and the existing plants at the Dresden site. These can be summarized as follows.

- The present temperatures of the Waterway leaving the Chicago area are considerably elevated above natural conditions. The analysis suggests inputs of heat to the Des Plaines River on the order of 1,200 to $1,500 \mathrm{MW}$ at the present time. 
- The operation of Dresden I is easily traceable down to the lower limit of this study. The plant raises the annual average by 0.2 to $0.3{ }^{\circ} \mathrm{C}$ during the year as far downstream as Marseilles, Illinois.

- The addition of the two newer and larger plants will have measurable temperature increases down to River Mile 230 , 39 miles below the plant site. Of additional significance is the determination that the greatest effect will occur in the winter months where, under conditions of $100 \%$ load factor, minimums will increase from 3 to $3.5^{\circ} \mathrm{C}$ over those present1y measured. The increase in maximum expected temperatures would be of lower magnitude, from 2.6 to $3.0{ }^{\circ} \mathrm{C}$. This is caused by evaporation being higher in the summer than the radiation losses which govern dissipation in the winter.

- An examination of the values of the B term, the amplitude variance, reveals that extensive heat additions tend to reduce the summer to winter changes significantly as a result of the high thermal inertia of the modified system, primarily in the winter months as indicated above.

Extensions of this study down to River Mile 80 are now in progress. These will include the accumulative effects of all currently foreseen projects.

The method described above has been used for a variety of analyses of the effects of the Hanford operation. The combination of the digital simulation system and the least squares modeling provides an objective basis for evaluating the gross effects of thermal modification. It is expected that methods of this type will find wide use in the adjudication and administration of water quality standards. This computational system is also applicable to conservative and first order nonconservative pollutants, such as radiation and bacteria, in 
the present stage of development. Applications to more complex systems involving dissolved oxygen, benthic and phytoplankton exchange, as well as surface re-aeration, are currently under investigation.

\section{ACKNOWLEDGEMENTS}

The author fully acknowledges the aid and advice of W. D. Mitchell and the staff of the United States Geological Survey who assisted the author by providing flow data and related hydrological information vital to the success of the simulation test. In addition, the help of the Survey in continuing to maintain and verify temperature recording instruments installed as part of this study is greatly appreaciated.

Further, the consulting advice of W. C. Ackermann, Director of the Illinois State Water Survey is appreciated.

Mr. I. C. Roberts, USAEC, Headquarters Office, aided in outling the scope of this study and was instrumental in the successful compilation and presentation of the subject material.

Data supporting this analysis and the extension to the lower Waterway that is to follow were supplied by the Chicago Office of the Federal Power Commission. The assistance of $\mathrm{Mr}$. L. B. Young, Regional Engineer, is acknowledged. 


\section{REFERENCES}

1. R. T. Jaske. The Use of Digital Systems Modeling in the Evaluation of Regional Water Quality involving Single and Multiple Releases, BNWL-SA-1372. Paper 46e, AICHE 60th Annual Meeting, November 26-30, 1967 .

2. W. R. Debler. "Stratified Flow into a Line Sink," J. Eng. Mech. Div., no. 2093 vol. 85, Juzy 1959.

3. R. T. Jaske. A Test Simulation of the Temperatures of the Deerfield River, BNWL-628. Pacific Northwest Laboratory, Richland, Washington, January 4, 1968.

4. R. T. Jaske. An Evaluation of the Use of Selective Discharges from Lake Roosevelt to Cool the Columbia River, BNWL-208. Pacific Northwest Laboratory, Richland, Washington, February 1966.

5. "Study Program to Determine the Potential Impact of Thermal Power Plants on Pacific Northwest Streams, "Contract Report to Fish Passage Research Program, USFWS, Bureau of Commercial Fisheries, October 1966 (Copies available from BCF, USFWS).

6. G. T. OrZob. "A Horizontalzy Stratified Reservoir Model," ASCE Specialty Conference, January 18-20, 1968.

7. "Water Loss Investigations: Lake Hefner Studies," Technical Report U.S. Geological Survey Professional Paper No. 269.

8. R. T. Jaske and J. B. Goebel. "Effects of Dam Construction on Temperatures of the Columbia River," Jour. AWWA vol. 58. August 1967 .

9. R. T. Jaske. "Thermal Modification of Water. Quality," Proceedings 6th Bienniel W.S.U. Hydraulics Conference, October 18-19, 1967 . 
BNWL - 728

APPENDIX A

SUPPORTING DATA 
TABLE A.1. IZZinois River Dimensions Between Mile 278 and 230 used in Test Simulation

\begin{tabular}{|c|c|c|c|}
\hline $\begin{array}{c}\text { TRGH } \\
\text { NO. }\end{array}$ & $\begin{array}{l}\text { UPSTREAM } \\
\text { SURFACE }\end{array}$ & $\begin{array}{l}\text { WIDTHS } \\
\text { BOTTOM }\end{array}$ & $\begin{array}{l}\text { UPSTREAM } \\
\text { DEPTH }\end{array}$ \\
\hline 1 & $9.3800+02$ & $5.0000+01$ & $1.2600+01$ \\
\hline 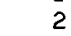 & $2.1750+03$ & $5.0000+01$ & $8.6000+00$ \\
\hline $\mathrm{J}$ & $2.6250+03$ & $1.5000+02$ & $9.6000+00$ \\
\hline 4 & $1.3630+03$ & $6.3800+02$ & $1.2600+01$ \\
\hline 5 & $1.1250+03$ & $7.6300+02$ & $1.5600+01$ \\
\hline 0 & $1.1130+03$ & $6.3800+02$ & $1.6000+01$ \\
\hline 7 & $4.8800+02$ & $3.5000+02$ & $1.1300+01$ \\
\hline 8 & $5.5000+02$ & $2.7500+02$ & $1.1500+01$ \\
\hline 9 & $5.6300+02$ & $3.2500+02$ & $1.1500+01$ \\
\hline 10 & $5.6300+02$ & $2.1300+02$ & $1.1800+01$ \\
\hline 11 & $5.2500+02$ & $3.0000+02$ & $1.2200+01$ \\
\hline 12 & $5.8800+02$ & $3.2500+02$ & $1.1600+01$ \\
\hline 13 & $4.8100+02$ & $2.4400+02$ & $1.3600+01$ \\
\hline 14 & $6.5600+02$ & $3.0000+02$ & $1.1800+01$ \\
\hline 15 & $5.3800+02$ & $3.1300+02$ & $1.3600+01$ \\
\hline 16 & $5.1300+02$ & $2.7500+02$ & $1.3600+01$ \\
\hline 17 & $5.1900+02$ & $2.7500+02$ & $1.3600+01$ \\
\hline 18 & $3.6800+02$ & $1.8800+02$ & $1.3700+01$ \\
\hline 19 & $5.8800+02$ & $3.0000+02$ & $1.4400+01$ \\
\hline 20 & $6.1900+02$ & $2.5000+02$ & $1.5600+01$ \\
\hline 21 & $5.7500+02$ & $3.2500+02$ & $1.5800+01$ \\
\hline 22 & $5.7500+02$ & $2.7500+02$ & $1.4500+01$ \\
\hline 23 & $6.9400+02$ & $3.2500+02$ & $1.1800+01$ \\
\hline 24 & $7.4400+02$ & $4.7500+02$ & $1.1500+01$ \\
\hline 25 & $5.8800+02$ & $2.3800+02$ & $1.5500+01$ \\
\hline 26 & $5.8800+02$ & $3.0000+02$ & $1.4700+01$ \\
\hline 27 & $7.6900+02$ & $3.8100+02$ & $1.4400+01$ \\
\hline 28 & $7.3100+02$ & $3.1900+02$ & $1.5500+01$ \\
\hline 29 & $6.8800+02$ & $3.5000+02$ & $1.4900+01$ \\
\hline 30 & $.7500+02$ & $5.0000+02$ & $1.1300+01$ \\
\hline 31 & $6.5000+02$ & $4.7500+02$ & $1.3400+01$ \\
\hline 32 & $1.0500+03$ & $7.2500+02$ & $1.3400+01$ \\
\hline 33 & $5.2500+02$ & $3.1000+01$ & $1.1500+01$ \\
\hline 34 & $7.0000+02$ & $2.5000+01$ & $1.0800+01$ \\
\hline 35 & $5.6300+02$ & $2.3800+02$ & $1.2300+01$ \\
\hline 36 & $6.1900+$ & $4.0300+02$ & $1.0800+01$ \\
\hline 37 & $6.3600+02$ & $3.5000+02$ & $1.1000+01$ \\
\hline 38 & $9.6300+02$ & $3.8100+02$ & $9.7000+00$ \\
\hline 39 & $6.2500+02$ & $1.0600+02$ & $2.3100+01$ \\
\hline 40 & $.2130+03$ & $2.2500+02$ & $1.4500+01$ \\
\hline 41 & $1.1810+03$ & $3.0000+02$ & $1.4800+01$ \\
\hline 42 & $1.1440+03$ & $2.9400+02$ & $1.7000+01$ \\
\hline 43 & $0000+03$ & $2.0000+02$ & $1.3000+01$ \\
\hline 44 & $8810+03$ & $2.7500+02$ & $1.6900+01$ \\
\hline 45 & $4.4750+03$ & $1.0000+02$ & $9.3000+00$ \\
\hline 46 & 3.350 & $1.0000+02$ & $1.2000+01$ \\
\hline 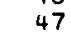 & $2.4380+03$ & $1.0000+02$ & $1.6200+01$ \\
\hline
\end{tabular}

TOTAL SURFACE AREA $=2.6365+08 \mathrm{SQ} . \mathrm{FT}$

DOWNSTREAM
SURFACE
$2.1750+03$
$2.6250+03$
$1.3630+03$
$1.1250+03$
$1.1130+03$
$4.8800+02$
$5.5000+02$
$5.6300+02$
$5.6300+02$
$5.2500+02$
$5.8800+02$
$4.8100+02$
$6.5600+02$
$5.3800+02$
$5.1300+02$
$5.1900+02$
$3.6800+02$
$5.8800+02$
$6.1900+02$
$5.7500+02$
$5.7500+02$
$6.9400+02$
$7.4400+02$
$5.8800+02$
$5.8800+02$
$7.6900+02$
$7.3100+02$
$6.8800+02$
$7.7500+02$
$6.5000+02$
$1.0500+03$
$5.2500+02$
$7.0000+02$
$5.6300+02$
$6.1900+02$
$6.3800+02$
$9.6300+02$
$6.2500+02$
$1.2130+03$
$1.1810+03$
$1.1440+03$
$2.0000+03$
$1.5810+03$
$4.4750+03$
$3.3500+03$
$2.4380+03$
$1.6130+03$

IDTHS

$5.0000+01$ $1.5000+02$ $7.3800+02$ $6.3800+02$ $3.5000+02$ $2.7500+02$ $3.2500+02$ $2.1300+02$ $3.0000+02$ $3.2500+02$ $2.4400+02$ $3.0000+02$ $3.1300+02$ $2.7500+02$ $2.7500+02$ $1.8800+02$ $3.0000+02$ $2.5000+02$ . $2500+02$ $2.7500+02$ $4.7500+02$ $4.7500+02$ $2.3800+02$ $3.8100+02$ $3.1900+02$ $3.5000+02$ $5.0000+02$ $4.7500+02$ $7.2500+02$ $3.1000+01$ $2.5000+01$ 2. $3800+02$ $4.0300+02$ $3.5000+02$ $3.8100+02$ $1.0600+02$ $2.2500+02$ $3.0000+02$ $2.9400+02$ $2.0000+02$ $2.7500+02$ $1.0000+02$ $1.0000+02$ $6.5000+02$

DOWISTREAM
UEPTH
$8.6000+00$
$9.6000+00$
$1.2600+01$
$1.5600+01$
$1.6000+01$
$1.1300+01$
$1.1500+01$
$1.1500+01$
$1.1800+01$
$1.2200+01$
$1.1600+01$
$1.3600+01$
$1.1800+01$
$1.3600+01$
$1.3600+01$
$1.3600+01$
$1.3700+01$
$1.4400+01$
$1.5600+01$
$1.5800+01$
$1.4500+01$
$1.1800+01$
$1.1500+01$
$1.5500+01$
$1.4700+01$
$1.4400+01$
$1.5500+01$
$1.4900+01$
$1.1300+01$
$1.3400+01$
$1.3400+01$
$1.1500+01$
$1.0800+01$
$1.2300+01$
$1.0800+01$
$1.1000+01$
$9.7000+00$
$2.3100+01$
$1.4500+01$
$1.4800+01$
$1.7000+01$
$1.3000+01$
$1.0900+01$
$9.3000+00$
$1.2000+01$
$1.0200+01$
$2.0700+01$
.

LENGTH
$2.6400+03$
$3.6960+03$
$1.7424+04$
$3.6960+03$
$5.2800+03$
$9.5040+03$
$2.6400+03$
$2.6400+03$
$5.2800+03$
$5.2800+03$
$5.2800+03$
$5.2800+03$
$5.2800+03$
$2.6400+03$
$2.6400+03$
$5.2800+03$
$5.2800+03$
$5.2800+03$
$5.2800+03$
$5.2800+03$
$5.2800+03$
$5.2800+03$
$5.2800+03$
$5.2800+03$
$5.2800+03$
$5.2800+03$
$5.2800+03$
$5.2800+03$
$5.2800+03$
$5.2800+03$
$5.2800+03$
$5.2800+03$
$5.2800+03$
$5.2800+03$
$5.2800+03$
$5.2800+03$
$5.2800+03$
$5.2800+03$
$5.2800+03$
$5.2800+03$
$5.2800+03$
$5.2800+03$
$5.2800+03$
$5.2800+03$
$5.2800+03$
$5.2800+03$
$5.2800+03$
5
SQ-FT $8.8704+06$ $3.4743+07$ $4.5978+06$ $7.6080+06$ $1.3702+06$ $1.4692+06$ $2.9726+06$ $2.8723+06$ $2.9383+06$ $2.8222+06$ 3. $0017+06$ $1.5761+06$ $1.3873+06$ $2.7245+06$ $2.3417+06$ $2.5238+06$ $3.1865+06$ $3.1522+06$ $3.3502+06$ $3.7963+06$ . $7935+06$ $3.1046+06$ $3.5825+06$ $3.9600+06$ $3.7462+06$ $3.8623+06$ $3.7620+06$ $4.4880+06$ $4.1580+06$ $3.2340+06$ $3.3343+06$ $3.1205+06$ $3.3185+06$ $4.2266+06$ $4 \cdot 1923+06$ $4.8523+06$ $6.3202+06$ $6.1380+06$ $8.3002+06$ $9.4538+06$ $1.5988+07$ 2. $0658+07$ $1.5280+07$
$1.0695+07$
VOLUME CU-FT $2.1934+07$ $2.2924+08$ $5.0615+07$ $7.5883+07$ $8.5667+07$ $1.2512+07$ $1.3002+07$ $2.5582+07$ $2.5364+07$ $2.7160+07$ $2.8089+07$ $1.5125+07$ $1.4712+07$ $2.8400+07$ $2.4319+07$ $2.6832+07$ $3.4784+07$ $3.6662+07$ $3.5011+07$ $3.2342+07$ $3.6096+07$ $3.6096+07$ $3.4153+07$ $4.3391+07$ $4.1895+07$ $3.9809+07$ $3.9055+07$ $5.1295+07$ $3.8817+07$ $1.8828+07$ $2.3290+07$ $2.7721+07$ $3.1758+07$ . $3112+07$ $5.2488+07$ $5.6450+07$ $6.1243+07$ $7.1362+07$ $1.0666+08$ $1.1215+08$ $1.1061+08$ 


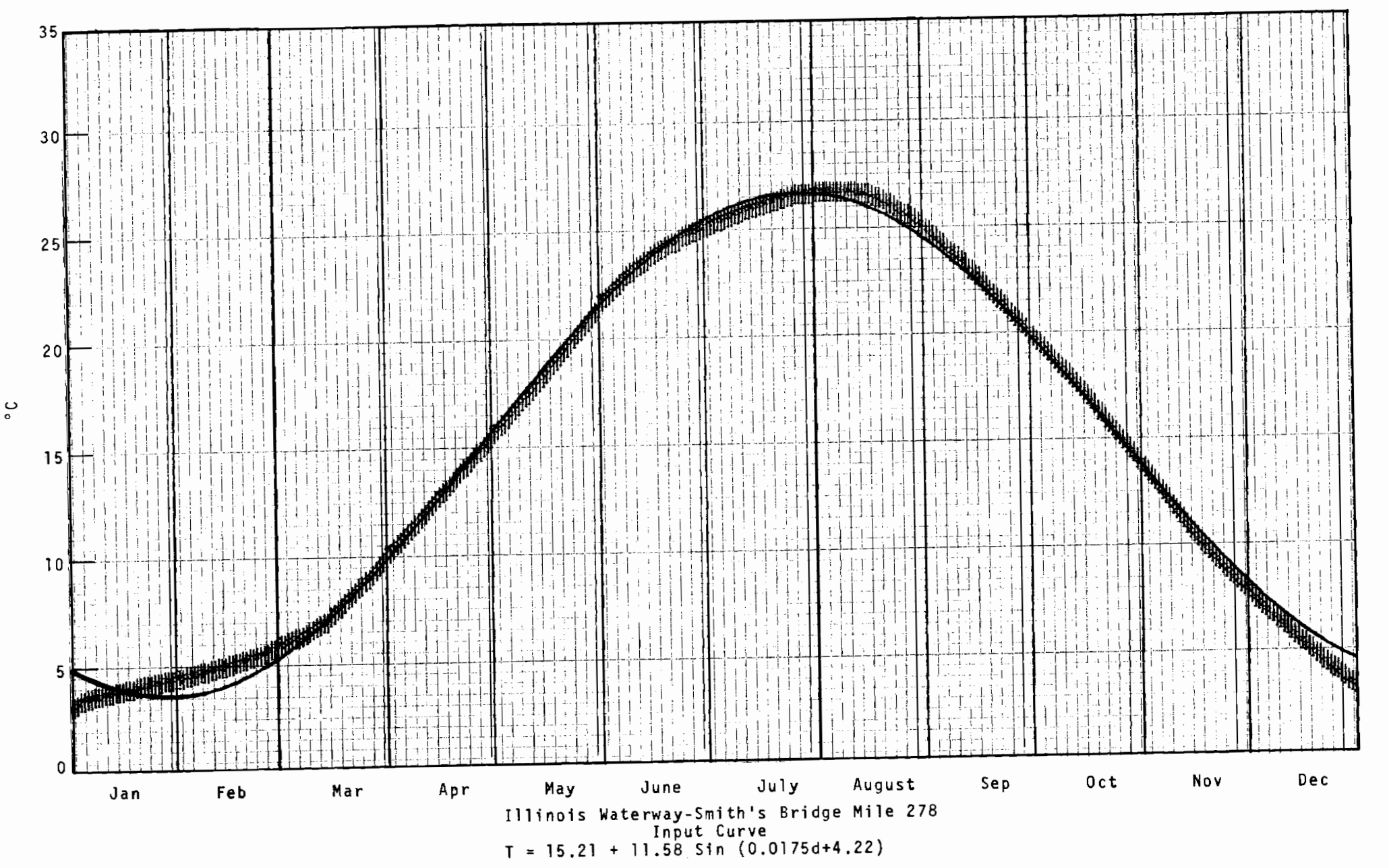




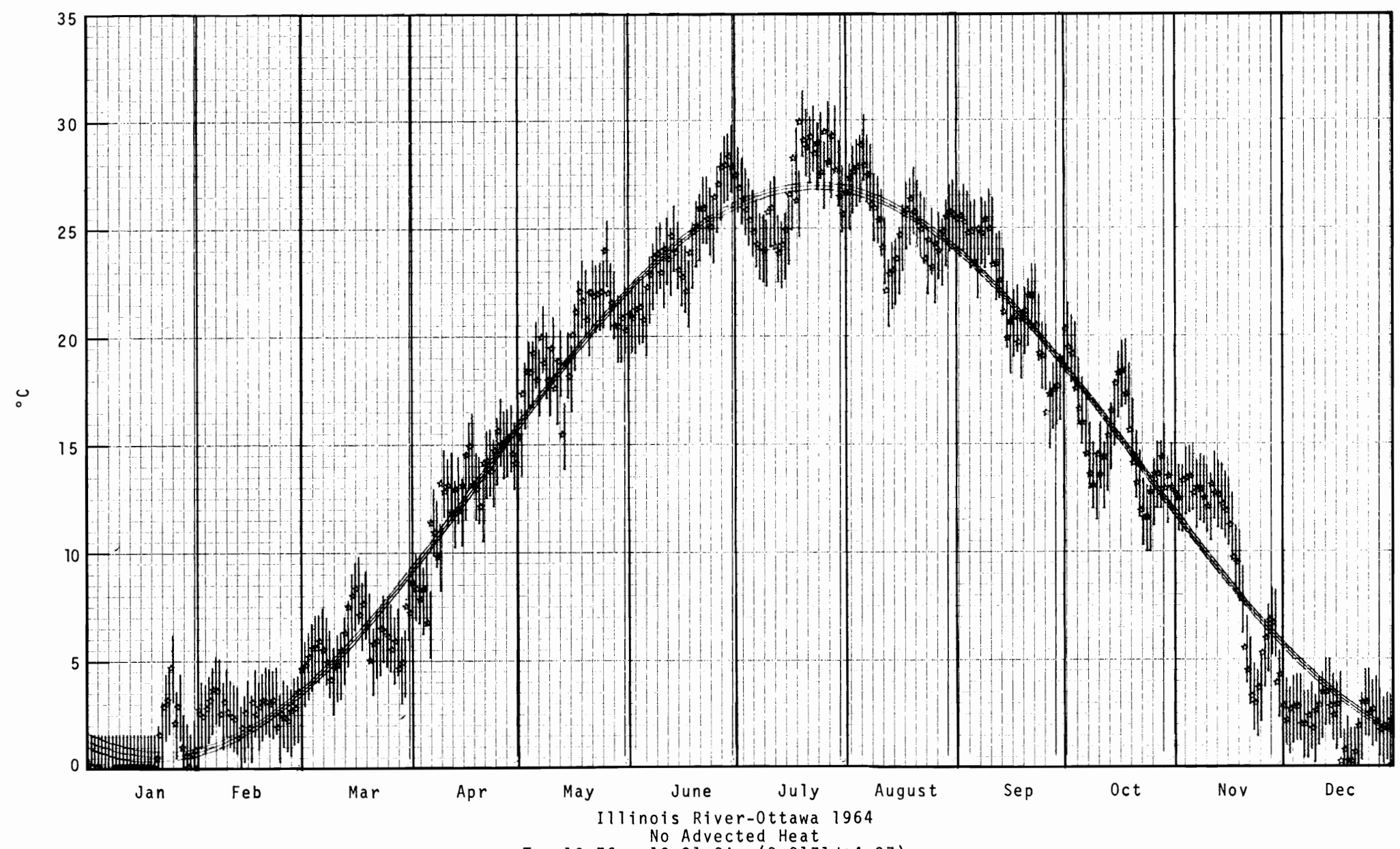

$T=13.76+13.21$ Sin $(0.0171 d+4.37)$ 


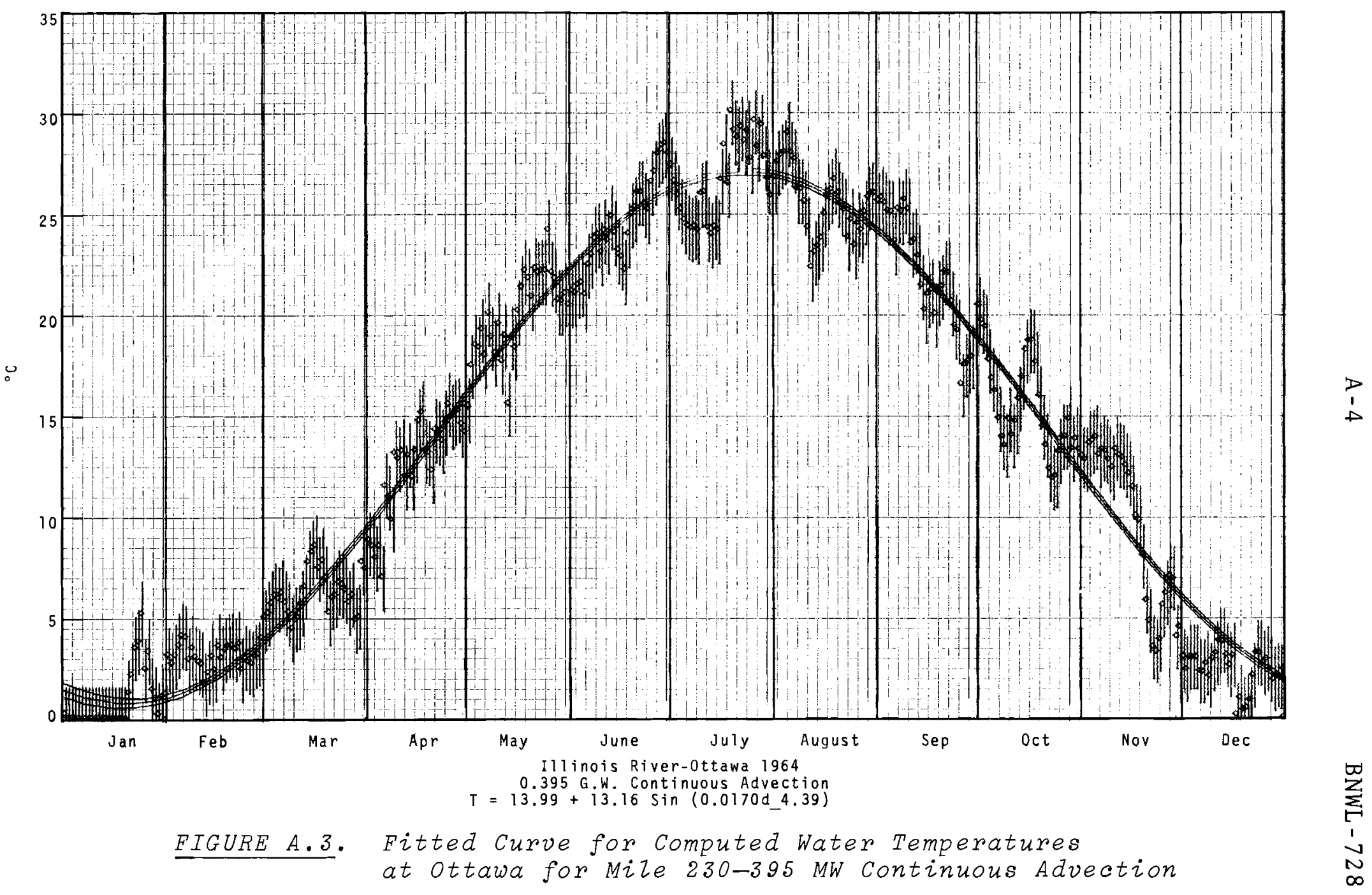




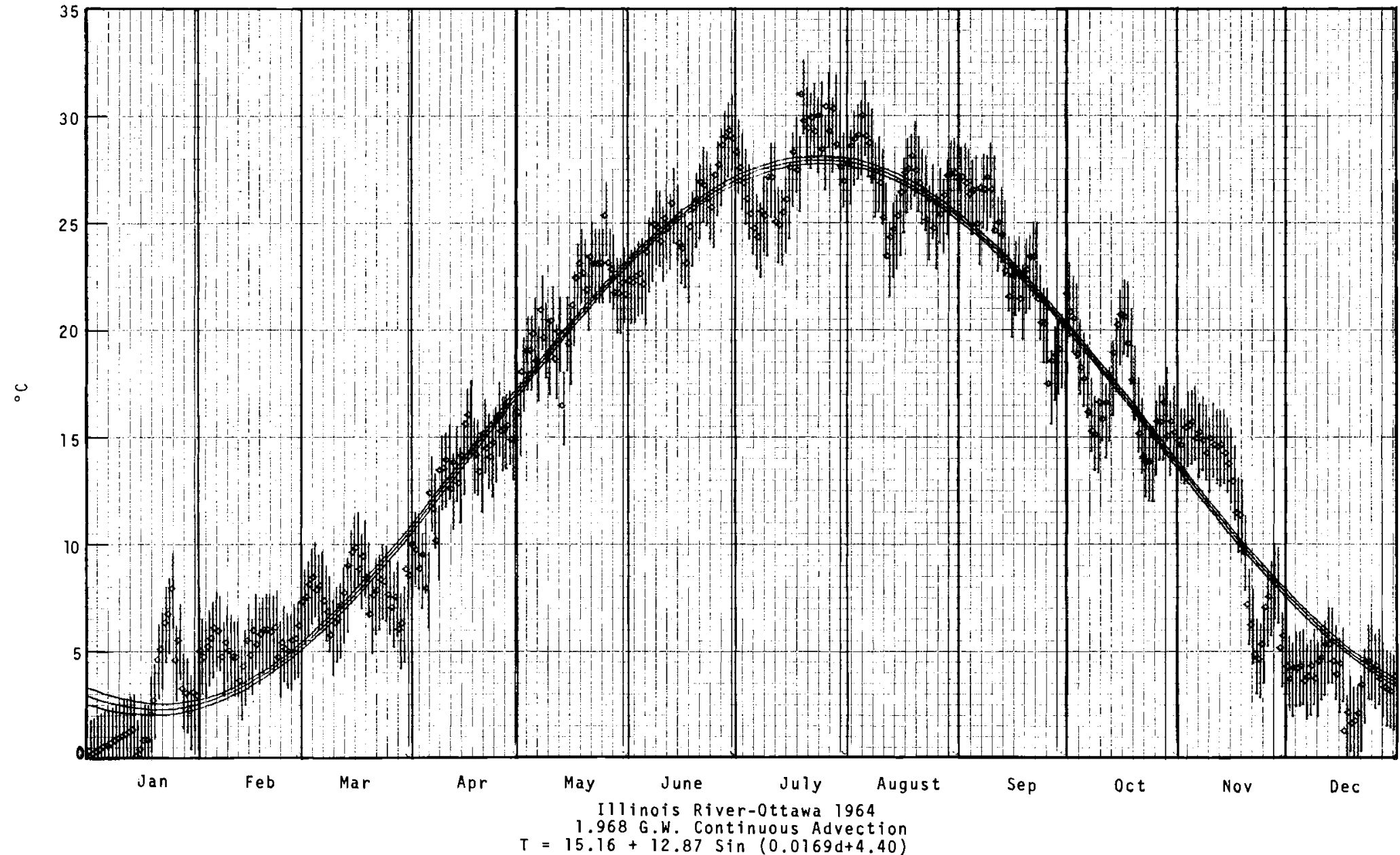

FIGURE A.4. Fitted Curve for Computed Water Temperatures at ottawa for Mile 230-1,968 MW Continuous Advection 


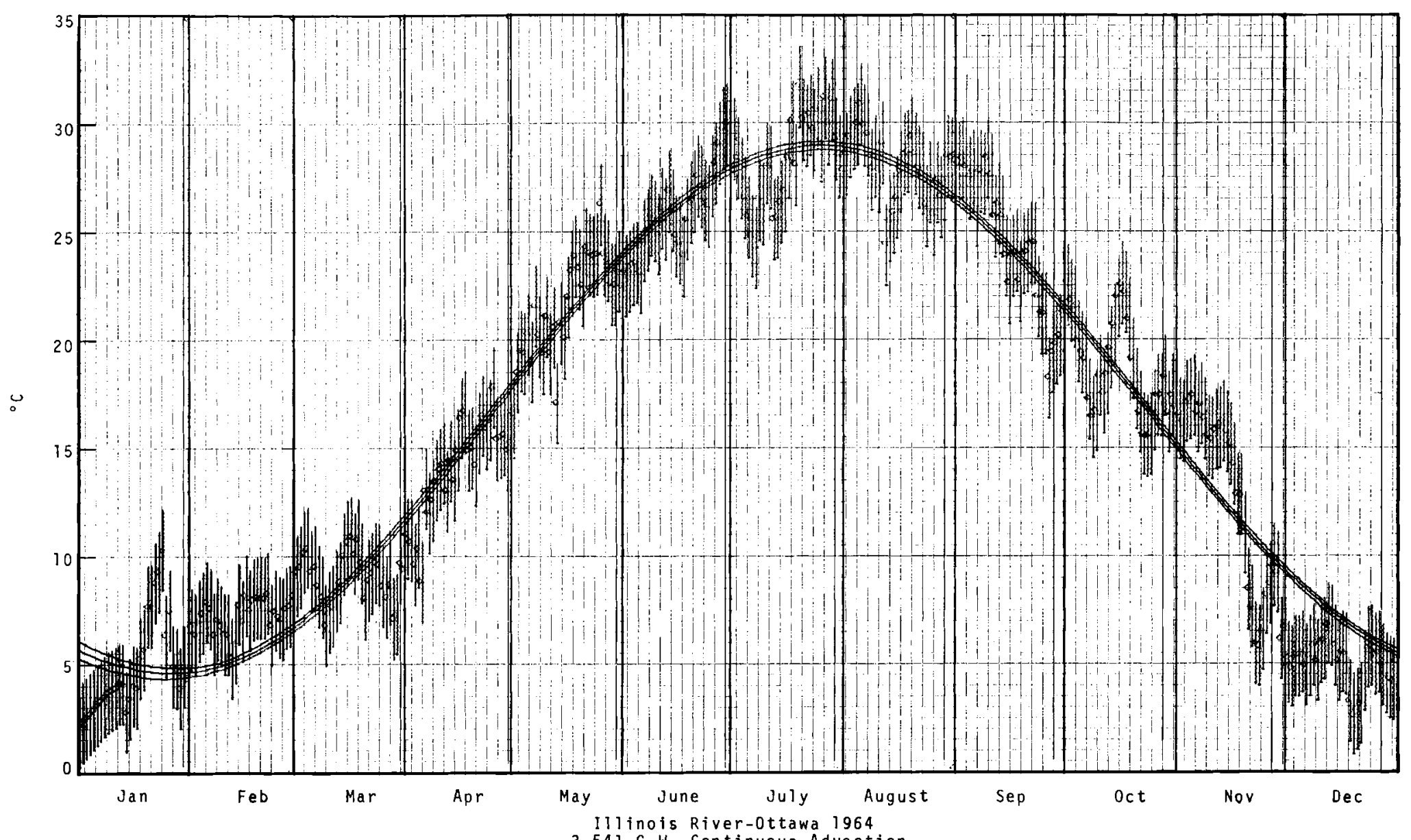

$\stackrel{1}{a}$

$T=16.89+12.22 \sin (0.0174 d+4.27)$

FIGURE A.5. Fitted Curve for Computed Water Temperatures at ottawa for Mile 230-1,968 MW

Continuous Advection Plus 1,573 MW Intermittent 


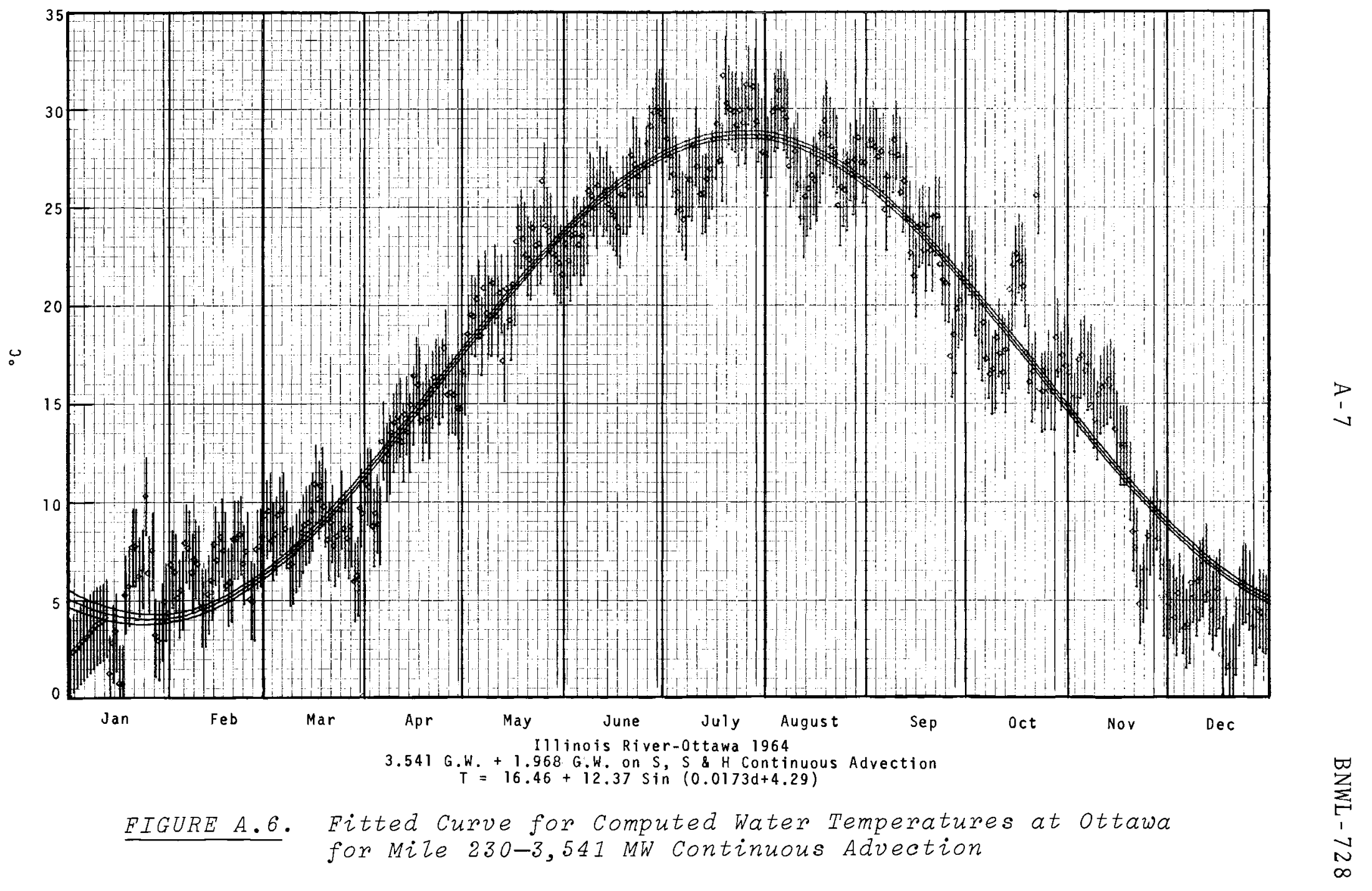




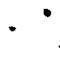




\section{DISTR I BUTION}

No. of

Copies

2

270

10

\section{AEC Chicago Patent Group}

C. H. Lee

R. K. Sharp

AEC Division of Technical Information Extension

AEC Library, Washington

Division of Reactor Development and Technology

W. G. Belter

I. C. Roberts

Division of Intelligence

C. H. Reichart

Division of Isotope Development

R. Butinhoff

Division of Operational Safety

A. A. Schoen

Division of Biology and Medicine

John Wolfe

2

AEC RDT Site Representative - PNL

P. G. Holsted

6

AEC Richland Operations Office

W. Devine

C. L. Robinson

M. W. Tiernan

Technical Information Files

1

American Institute of Chemical Engineers

900 W. Orange Grove Road

Tucson, Arizona 85704

Lawrence Cecil

6

Batte1le Memorial Institute

F. A. Butrico

G. E. Raines

Columbus Files

H. R. Hamilton 
F. A. Limpert

British Columbia Hydro and Power Authority 970 Burrard Street

Vancouver, B. C. Canada

T. F. Daggs

Chelon County Public Utility District

P.0. Box 1231

Wenatchee, Washington

J.H. Schrengohst

Computer Sciences Corporation

J. L. Spurgeon

Commonwea1th Edison Company

72 West Adams Street

Chicago, I11 inois

W. B. Behnke Jr.

Department of Energy, Mines and Resources ottawa 4, Ontario, Canada

E. R. Tinney

Douglas United Nuclear

R. G. Geier

File

Edison Electric Institute 750 Third Ave.

New York, New York 10017

J. Mason Guil1ory

Federal Power Commission 610 S. Canal Street Chicago, Illinois 60607

L. B. Young 
No. of

Copies

New York State Department of Conservation

Albany, New York

N. L. Barbarossa

L. G. Hetling

1

2

1

2

1

1

1

Oak Ridge National Laboratory

Building 9201-3

P.O. BoX Y

Oak Ridge, Tennessee 37830

Samuel E. Bea11, Jr.

Portland General Electric Company

621 S.W. Alder Street

Portland, Oregon 97205

L. E. Hodel

E. C. Itschner

State Sanitary Authority

State Office Bldg.

Portland, Oregon 97201

Kenneth $H$. Spies

Tennessee Valley Authority

410 Edney Bldg.

Chattanooga, Tennessee

Milo Churchill

Norris, Tennessee

Rex Elder (1)

U.S. Army Corps of Engineers, North Pacific Div. 417 Custom House

Portland, Oregon

David M. Rockwood

U.S. Army Corps of Engineers, North Pacific Div. Walla Walla District Office

Walla Walla, Washington

Melvin Ord

U.S. Army Corps of Engineers, Ohio River Div.

550 Main Street

Cincinnati, Ohio 45202

Glenn H. Von Gunten 
No. of

Copies

2

U.S. Army Corps of Engineers, Seattle District

1519 Alaskan Way South

Seattle, Washington 98134

Patrick Keough

Norman McDonald

1

U.S. Army Corps of Engineers, Portland District

Pittock Block

Portland, Oregon 97205

Peter Boyer

1 U.S. Department of Interior

Bureau of Commercial Fisheries

P.O. Box 4332

Portland, Oregon 97205

L. E. Perry

2

U.S. Department of Interior

Bureau of Commercial Fisheries

2725 Montlake Blvd.

Seattle, Washington 98102

G. B. Collins

G. R. Snyder

2

U.S. Department of Interior

Bureau of Reclamation

6728 Pomona Street

Boise, Idaho

J. C. Peterson

G. Shirk

1

U.S. Department of Interior

office of Water Resources Research

Washington, D.C.

Eugene D. Eaton

1

U.S. Department of Interior

Water Resources Division

2300 John F. Kennedy Bldg.

Boston, Massachussetts 02203

C. E. Knox

1

U.S. Geodetic Survey

Water Resources Division

1305 Tacoma Ave., South

Tacoma, Washington 98402

W. D. Simons 


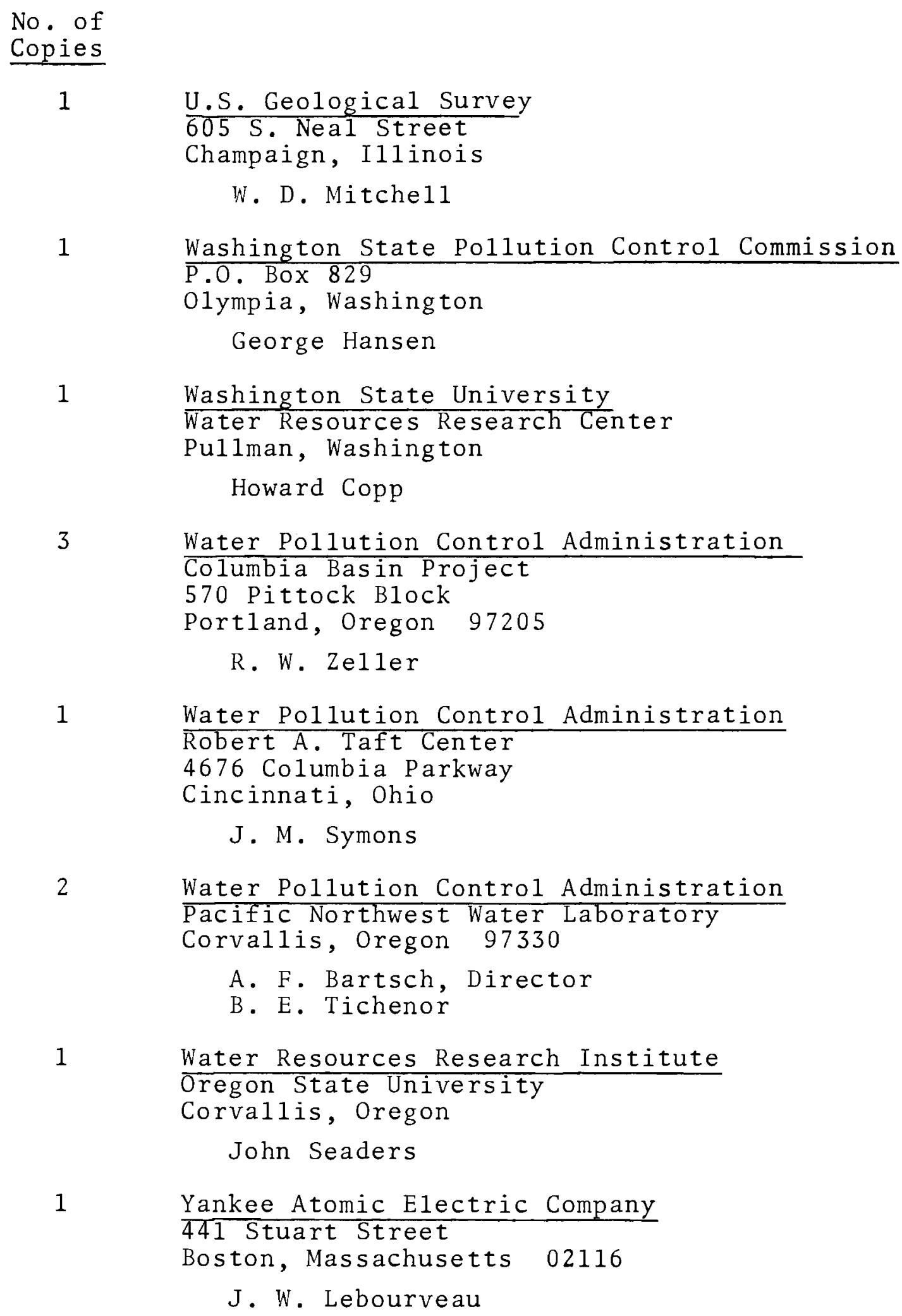

U.S. Geological Survey

605 S. Neal Street

Champaign, Illinois

W. D. Mitche11

1 Washington State Pollution Control Commission

P.0. Box 829

Olympia, Washington

George Hansen

$1 \quad$ Washington State University

Water Resources Research Center

Pullman, Washington

Howard Copp

3

Water Pollution Control Administration

Columbia Basin Project

570 Pittock Block

Portland, Oregon 97205

R. W. Ze11er

1 Water Pollution Control Administration

Robert A. Taft Center

4676 Columbia Parkway

Cincinnati, Ohio

J. M. Symons

2

Water Pollution Control Administration

Pacific Northwest Water Laboratory

Corvallis, Oregon 97330

A. F. Bartsch, Director

B. E. Tichenor

1

Water Resources Research Institute

Oregon State University

Corvallis, Oregon

John Seaders

1

Yankee Atomic Electric Company

441 Stuart Street

Boston, Massachusetts 02116

J. W. Lebourveau 
No. of

Copies

73
Battelle-Northwest

R. F。Corlett

J.P.Corley

C. C. Coutant

J. F. Fletcher

R. F, Foster

W. A. Haney

J. F. Honstead

R. T. Jaske

M. H. Karr

L. P. King

R。E。Nakatani

R. L. Reynolds

G. A. Sawyer

W. L. Templeton

C. J. Touhill

W. A. Watts

Technical Information Files

Technical Publications

G. M. Dalen 